\title{
Cambrian Furongian Series acritarchs from the Comley area, Shropshire, England
}

\author{
TIMOTHY L. POTTER ${ }^{1 *}$, BRIAN E. PEDDER ${ }^{1,2} \&$ SUSANNE FEIST-BURKHARDT $^{3,4}$ \\ ${ }^{1}$ Palaeontology Department, The Natural History Museum, Cromwell Road, London SW7 5BD, UK \\ ${ }^{2}$ Department of Animal and Plant Sciences, University of Sheffield, Western Bank, Sheffield S10 2TN, UK \\ ${ }^{3}$ Institute for Applied Geosciences, Darmstadt University of Technology, Schnittspahnstrasse 9, D-64287 Darmstadt, Germany \\ ${ }^{4}$ SFB Geological Consulting \& Services, Odenwaldstrasse 18, D-64372 Ober-Ramstadt, Germany \\ *Corresponding author (e-mail: timlyallpotter@hotmail.com)
}

\begin{abstract}
Acritarch assemblages are reported for the first time from the Cambrian of Comley, Shropshire, England, a historically important area for British Cambrian biostratigraphy. Three assemblages are described from the Furongian Shoot Rough Road Shales. Horizons within the Shoot Rough Road Shales have in the past yielded Parabolina spinulosa and Orusia lenticularis indicative of the Parabolina spinulosa trilobite Zone. Two distinct microfloras are identified, one is characterized by the common occurrence of Trunculumarium revinium and diacrodian taxa, the other, by an absence of $T$. revinium and a general paucity of diacrodians but with a significant presence of Scalenadiacrodium comleyense gen. et sp. nov. The microfloras are compared with trilobite-controlled Furongian sequences in eastern Newfoundland and the Nuneaton area, England and are found to support the P. spinulosa Zone assignment for the Shoot Rough Road Shales. The microfloras are also compared with those from localities lacking direct P. spinulosa Zone trilobite control, principally the Ardennes and the East European Platform. Acritarch based recognition of the two trilobite subzones of the $P$. spinulosa Zone remains problematic, but independent subdivision of the zonal interval based on acritarchs is supported. A new acritarch genus Scalenadiacrodium gen. nov. and a new species S. comleyense sp. nov. are described. J. Micropalaeontol. 31(1): 1-28, February 2012.
\end{abstract}

KEYWORDS: acritarchs, Cambrian, Furongian, Comley, P. spinulosa Zone, trilobite

\section{INTRODUCTION AND GEOLOGICAL BACKGROUND}

The Comley area and surrounding districts provide one of a small number of Cambrian outcrops in England, all of limited geographical extent (Fig. 1), but Comley's geological importance is disproportionate to its size. Lapworth (1888) described the first early Cambrian trilobites to be found in Britain from Comley Quarry (Fig. 2) and the condensed carbonate section exposed there is still a major reference for Cambrian biostratigraphy world-wide. With the exception of the quarry section, the solid geology of the area is very poorly exposed and knowledge of the succession is owed mainly to the studies of E. S. Cobbold, undertaken with the aid of numerous excavations, during the early part of the twentieth century. A discontinuous sequence of Terreneuvian to Furongian sedimentary rocks is present.

An account of the Cambrian sequence in the area is provided by Greig et al. (1968) and is used as the basis for the geological description given below. A concise description of the Comley Quarry outcrop is given by Rushton (in Rushton et al., 1999). The very poorly exposed Furongian Shoot Rough Road Shales are the subject of the present investigation (Fig. 3). The shales were deposited in a relatively shallow-marine environment and represent a transition between the dominantly shallow-marine, more arenaceous, Terreneuvian to Series 3 sediments of the area and the deeper-marine facies of Furongian and Lower Ordovician deposits. Although the true thickness is not determinable, $28.93 \mathrm{~m}$ (94'11") of the shales are seen to be resting with non-sequence on the Series 3 Shoot Rough Road Flags in the Geological Survey inclined borehole [National Grid 4889 9645] at Shoot Rough (Greig et al., 1968). The Shoot Rough Road Shales are succeeded by the Tremadocian (Lower Ordovician) Shineton Shales in the Comley area, known from stream sections in woodland north of Shoot Rough, which have yielded a fauna including Rhabdinopora flabelliformis (Eichwald, 1840). To the north of the area, at
Bentleyford Brook, black Furongian shales (Bentleyford Shales) separate the Shoot Rough Road Shales from the overlying Tremadocian Shineton Shales (Stubblefield, 1930). The apparent absence of these shales in the Comley area is most probably due to faulting, a faulted contact being tentatively suggested to occur between the Shineton Shales and older strata in Cobbold's Excavation 62 in Shoot Rough Wood (Cobbold, 1927).

Recent palaeontological investigations have again focused on the mainly Series 2 carbonate succession exposed at Comley Quarry. Hinz (1987) described the phosphatic microfossils and Siveter et al. (2001) report exceptionally well-preserved phosphatocopid crustaceans. The Furongian clastic sequence has been largely neglected since the time of Cobbold's work, although the acritarchs from the Tremadocian Shineton Shales north of the study area have been thoroughly investigated (Downie, 1958; Rasul, 1979). In this contribution we describe acritarch assemblages from three samples of the Shoot Rough Road Shales. Cobbold (1927) recovered the trilobite Parabolina spinulosa (Wahlenberg, 1821), diagnostic of the Parabolina spinulosa Zone (Furongian Series, Cambrian Stage 9, of recently introduced chronostratigraphical terminology, Cocks et al., 2010) from two excavations in the shales and two of the acritarch sample sites were located in the close neighbourhood of these excavations. The presence of $P$. spinulosa in the Shoot Rough Road Shales, as reported in Cobbold (1927), is indicative of the upper $P$. spinulosa Subzone of the $P$. spinulosa Zone (A.W.A. Rushton, pers. comm. 2009). Whilst the subdivision of the zone was introduced by Westergård in 1922, it was formally treated as a subzone by Westergård (1944) after Cobbold's death. The zonal subdivision is summarized by Henningsmoen (1957). C. J. Stubblefield, who identified the trilobite material reported by Cobbold, would have been aware of the description of Parabolona brevispina (Westergård, 1922), the index fossil for 
the lower subzone, and would not have confused the two taxa (Rushton, pers. comm. 2009). Unfortunately the excavations are now completely obscured and their exact location cannot be identified with certainty. The aims of the investigation were to characterize the Comley microfloras and to determine the potential of acritarchs as a tool for biostratigraphy in the Comley area by comparison with assemblages that have an established relationship with trilobite zones in other areas. The assemblages are compared with those from eastern Newfoundland (Martin \& Dean, 1981, 1988; Parsons \& Anderson, 2000) and with one from the Nuneaton area of the English Midlands (briefly reported by Bridge et al., 1998 and unpublished material), these being the only other Avalonian sequences with reliable $P$. spinulosa Zone control together with acritarch data. In addition, comparison is made with similar microfloras elsewhere, notably from the Ardennes and Estonia, where the trilobite evidence is more tenuous or absent.

\section{SAMPLING}

Three samples, L1, L2 and L3, were collected from the Furongian Shoot Rough Road Shales of the Comley area and prepared for palynological investigation. The sampling was based primarily on the fieldwork carried out by E. S. Cobbold, published between 1909 and 1933 and summarized with additional borehole information by Greig et al. (1968). Cobbold's map (Cobbold, 1927) shows the location of 63 excavations. A previous palynological investigation of the Series 3 and Furongian of the Comley area by one of the authors (Potter, unpublished $\mathrm{PhD}$ thesis, University of Sheffield, 1974) was also used in the selection of sample sites. The very limited exposure proved the greatest constraint on site selection. Map references are according to the Ordnance Survey 1: 10,560, 6 inches to the mile, Sheet SO 49 NE. A simplified map showing the sample sites is given in Figure 2. The samples were all collected from small exposures of dark grey shale reported by Cobbold (1921) as Orusia Shales Horizon Ca, now and previously (see Cobbold 1921, table 1, 'Shoot-Rough Road Shale') called Shoot Rough Road Shales (Cowie et al., 1972). Greig et al. (1968) employ the term Grey (Orusia) Shales for the same lithological unit. The position of the Shoot Rough Road Shales in relation to the Cambrian stratigraphy of the Comley area is shown in Figure 3.

- L1: SO 49 NE 4857 9671. West bank of Comley Brook, approximately $2 \mathrm{~m}$ north of the junction between Comley Brook and a small tributary running west from Shoot Rough. Site L1 is situated at or close to Excavation 60 reported by Cobbold (1927, p. 555). Excavation 60 yielded only a minute Lingulella, but the rock exposed was none the less provisionally assigned to the Orusia horizon, Ca. Excavation 59, c. 27 $\mathrm{m}$ to the south in Comley Brook, yielded Parabolina spinulosa (Wahlenberg, 1821), Orusia lenticularis (Wahlenberg, 1821) and Acrothele cf. coriacea Linnarsson, 1876 (Cobbold, 1916, p. 122; 1927, reporting work of C. J. Stubblefield, p. 557).

- L2: SO 49 NE 4871 9653. North bank of a tributary of Comley Brook running WNW from Shoot Rough Farm where it flows just to the south of and parallel to Shoot Rough Road. It is some $30 \mathrm{~m}$ downstream from the point where the stream initially converges with the road. Some of Cobbold's excavations just to the north of Shoot Rough Road exposed shales he assigned to the Shoot Rough Road Shales. Excavation No. 21, located some metres north of location L2 in the bank of Shoot Rough Road (now concealed), yielded a small form 'approaching' Orusia lenticularis, Kutorgina sp. and a small Acrothele (Cobbold, 1910, p. 185).

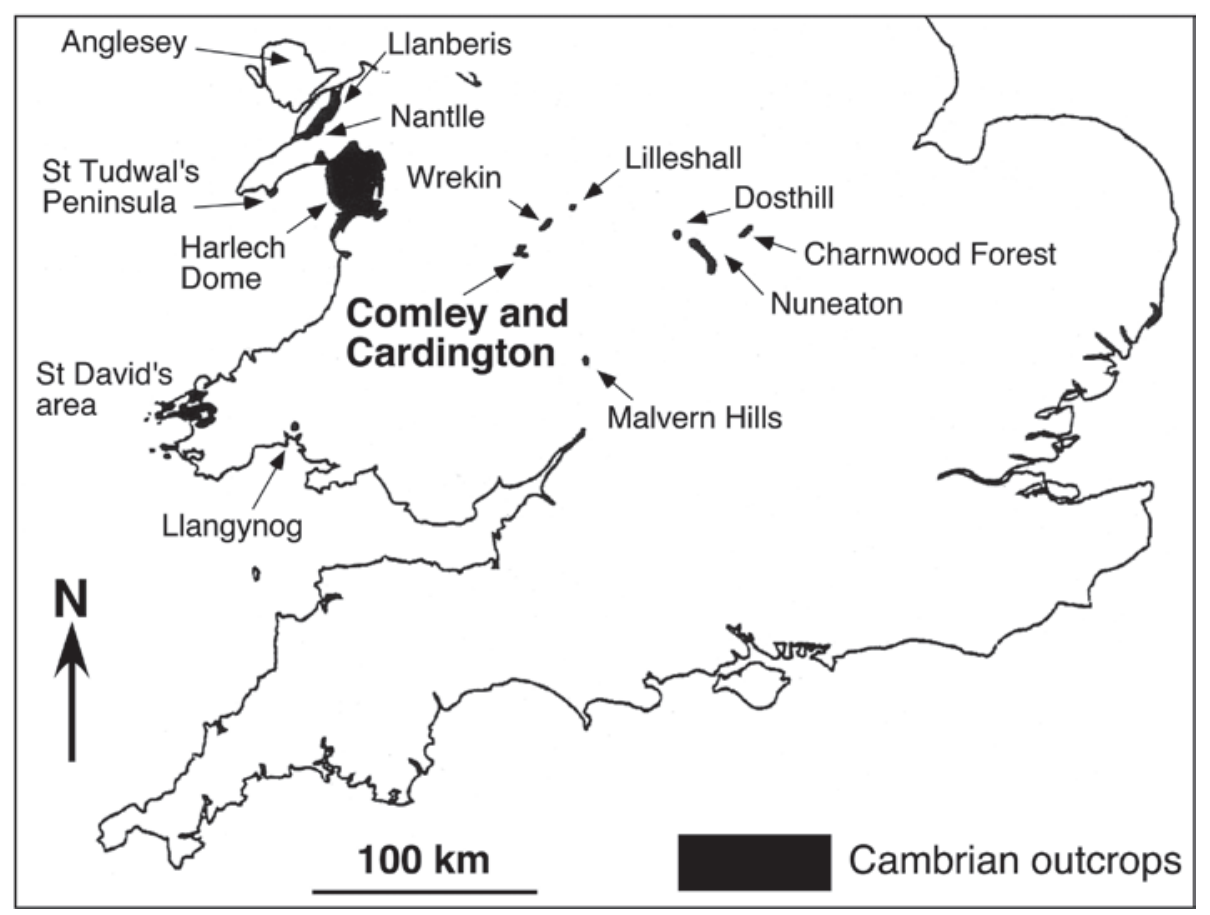

Fig. 1. Distribution of Cambrian outcrops in England and Wales (after Rushton in Rushton et al., 1999). 


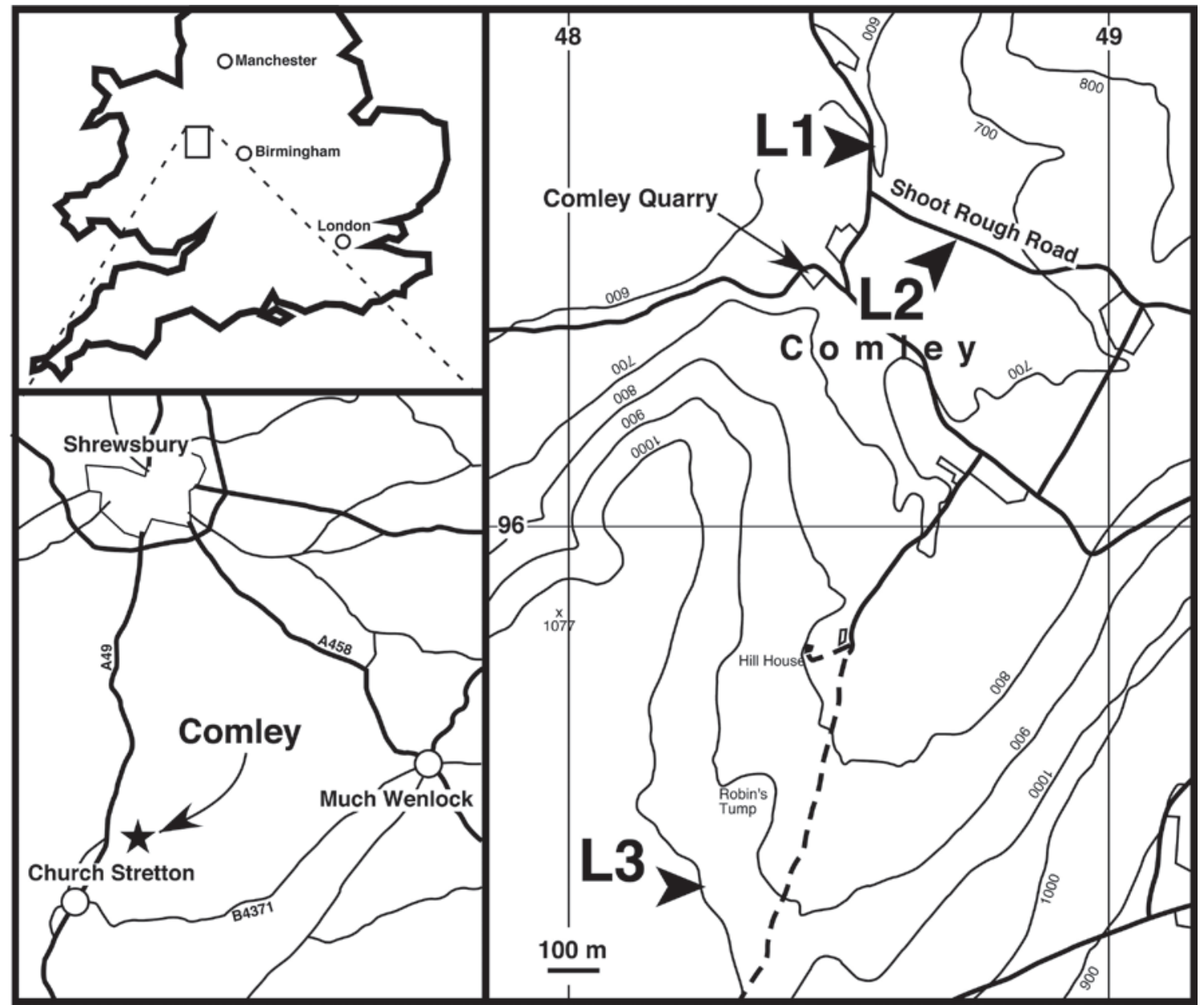

Fig. 2. Map showing sampled localities in the Comley area, Shropshire, UK (after Ordnance Survey map 1: 10,560, 6 inches to the mile, Sheet SO 49 NE).

\begin{tabular}{|c|c|c|c|}
\hline System & Series & Lithostratigraphy & $\begin{array}{c}\text { Thickness } \\
\text { (approximate) }\end{array}$ \\
\hline Ordovician & Tremadocian & Shineton Shales & \multirow{3}{*}{ ? 300m } \\
\hline \multirow{14}{*}{$\begin{array}{l}\frac{c}{0} \\
\frac{\pi}{1} \\
\frac{0}{E} \\
\text { U }\end{array}$} & \multirow[b]{2}{*}{ Furongian } & Bentleyford Shales & \\
\hline & & $\begin{array}{l}\text { Shoot Rough Road Shales* } \\
\text { (Grev (Orusia) Shales) }\end{array}$ & \\
\hline & \multicolumn{3}{|c|}{ hiatus } \\
\hline & \multirow{8}{*}{ Series 3} & Shoot Rough Road Flags & \multirow{7}{*}{90 to ?over $180 \mathrm{~m}$} \\
\hline & & Shoot Rough Road Sandstone & \\
\hline & & Hill House Shales & \\
\hline & & Hill House Grits & \\
\hline & & Hill House Flags & \\
\hline & & Quarry Ridge Shales & \\
\hline & & Quarry Ridge Grits & \\
\hline & & \multicolumn{2}{|l|}{ unconformity } \\
\hline & \multirow{2}{*}{ Series 2} & Comley Limestones & \multirow{2}{*}{ ca. $150 \mathrm{~m}$} \\
\hline & & Lower Comley Sandstone & \\
\hline & Terreneuvian & Wrekin Quartzite & up to $40 \mathrm{~m}$ \\
\hline
\end{tabular}

Fig. 3. Stratigraphy of the Cambrian sedimentary succession in the Comley area (after Greig et al., 1968; Cowie et al., 1972; Rushton pers. comm., 2008). Asterisk (*) indicates the provenance of samples L1, L2 and L3 of the present study. 
- L3: SO 49 NE 4825 9534. In a clump of trees, approximately $240 \mathrm{~m}$ and $190^{\circ}$ south of Robin's Tump (a small hillock) on the eastern slopes of Caer Caradoc. It is close to the site of excavation 43 (Cobbold, 1912, p. 115; 1927, p. 556), which exposed shales that Cobbold considered reminiscent of the Shoot Rough Road 'group' north of the Shoot Rough Road and yielded Orusia lenticularis and fragments of Parabolina spinulosa (according to C. J. Stubblefield, reported by Cobbold, 1927).

Fragments of shale showing the least signs of weathering were selected for preparation and standard palynological preparation procedures were employed. Testing with $10 \%$ hydrochloric acid indicated that calcium carbonate was absent and the samples were broken down in $60 \%$ hydrofluoric acid, undissolved mineral being removed using sodium polytungstate heavy mineral separation. Oxidation was not required and the residues were sieved to provide slides of the $5-10 \mu \mathrm{m}$ and the $>10 \mu \mathrm{m}$ fractions. The $5-10 \mu \mathrm{m}$ fraction is used for concentrating the very small acritarchs that might be present. In addition, a $5 \mu \mathrm{m}$ and greater fraction was mounted for each sample for establishing the relative abundance of species in a count of more than 300 identifiable specimens. All light photomicrographs were taken using Differential Interference Contrast. Scanning electron microscope (SEM) imaging was undertaken using a Philips XL30 Field Emission Gun SEM at the Natural History Museum, London.

\section{SYSTEMATIC PALYNOLOGY}

Previous occurrences are reported in instances where the identification of the taxon could be confirmed using illustrations of the taxon in the relevant publication. When the biozone is confirmed by external macrofossil control, this is indicated. Descriptions and remarks are given where considered relevant. Slides containing the figured specimens are deposited in the micropalaeontological collection of the Palaeontology Department, Natural History Museum, London. All acritarchs can be located within the slides using the England Finder references given for each specimen on the plate captions, e.g. K63/0. Dimensions are given in the convention: lowest (average) highest value.

\section{Species list}

The taxa recorded from the Comley samples are listed below.

Actinotodissus achrasii (Martin, 1973) Yin Lei-ming, 1986 (Pl. 1, figs 1,2 )

Cristallinium cambriense (Slavíková, 1968) Vanguestaine, 1978 (P1. 5, fig. 6; P1. 7, fig. 11)

Cristallinium randomense Martin in Martin \& Dean, 1981 (Pl. 5, figs 4 , 5; Pl. 7, fig. 12)

Cymatiogalea aff. aspergillum Martin in Martin \& Dean, 1988 (P1. 4, figs 1-3)

Cymatiogalea virgulta Martin in Martin \& Dean, 1988 (Pl. 3, figs 4-6; P1. 7, fig. 6)

Dasydiacrodium obsonum Martin in Martin \& Dean, 1988 (Pl. 1, figs 3,4$)$

Gyalorhethium? sp. 1 (P1. 3, fig. 9)

Impluviculus sp. 1 (Pl. 2, figs 1-3)

Leiofusa stoumonensis Vanguestaine, 1973 (Pl. 5, fig. 9)
Leiosphaeridia spp. (P1. 5, fig. 8)

Ninadiacrodium caudatum (Vanguestaine, 1973) Raevskaya \& Servais, 2009 (P1. 5, fig. 7)

Ninadiacrodium aff. caudatum (Vanguestaine, 1973) Raevskaya \& Servais, 2009 (Pl. 3, fig. 1)

Ninadiacrodium dumontii (Vanguestaine, 1973) Raevskaya \& Servais, 2009 (Pl. 2, fig. 9; Pl. 7, figs 1-3)

Polygonium spp. (P1. 1, figs 5, 6; P1. 7, fig. 4)

Scalenadiacrodium comleyense gen. et sp. nov. (P1. 2, figs 4-8)

Stelliferidium cortinulamorphum Paalits, 1995 (Pl. 4, figs 4-6; P1. 7, fig. 7)

Stelliferidium cf. distinctum (Rasul, 1974) Pittau, 1985 (Pl. 4, figs $7,8)$

Timofeevia aff. estonica Volkova, 1990 (Pl. 3, figs 7, 8; Pl. 7, figs $8,9)$

Timofeevia phosphoritica Vanguestaine, 1978 (Pl. 3, figs 2, 3; P1. 7, fig. 5)

Trunculumarium revinium (Vanguestaine, 1973) Loeblich \& Tappan, 1976 (Pl. 4, fig. 9; Pl. 5, figs 1-3; Pl. 7, fig. 10)

Vulcanisphaera africana Deunff, 1961 (Pl. 6, figs 1, 3)

Vulcanisphaera turbata Martin in Martin \& Dean, 1981 (Pl. 6, figs 2, 4)

\section{INCERTAE SEDIS \\ Group Acritarcha Evitt, 1963}

Genus Actinotodissus Loeblich \& Tappan, 1978

Type species. Actinotodissus longitaleosus Loeblich \& Tappan, 1978

Remarks. The status of the genus Actinotodissus is discussed in relation to the similar genera Acanthodiacrodium (Timofeev, 1958) Deflandre \& Deflandre-Rigaud, 1962, Diornatosphaera Downie, 1958 and Priscotheca Deunff, 1961 by Bagnoli et al. (1988), Martin in Martin \& Dean (1988), Parsons \& Anderson (2000) and Paalits \& Heuse (2000), amongst others. The forms discussed below clearly possess large hollow processes and are here assigned to the genus Actinotodissus in accordance with the views of Martin in Martin \& Dean (1988).

Actinotodissus achrasii (Martin, 1973) Yin Lei-ming, 1986 (Pl. 1, figs 1, 2)

1973 Acanthodiacrodium achrasi Martin: 30; pl. V, fig. 11; pl. VI, figs 8, 11, 19; pl. VIII, figs 1, 2, 4.

1986 Actinotodissus achrasi (Martin, 1973); Yin Lei-ming, 332; pl. 84, figs $1,3,5,7-11,13,15,16$; pl. 92, figs 1, 2, 4, 6; pl. 93, fig. 1, 2, 6, 7; pl. 94, fig. 5; pl. 96, fig. 4; pl. 97, fig. 8; text-fig. 122.

Description. The vesicle outline is elongate polygonal with long, hollow, broad-based, tapering, pointed processes inserted in the polar regions, often with one or two processes located in the otherwise unornamented central region, more or less equidistant from the poles. There are equal numbers of processes in each polar region or with a difference of no more than two. One or more processes on a given individual may be significantly shorter, approximately $1 / 3$ to $2 / 3$ the length of the principal processes. The process cavities are in communication with the vesicle cavity 


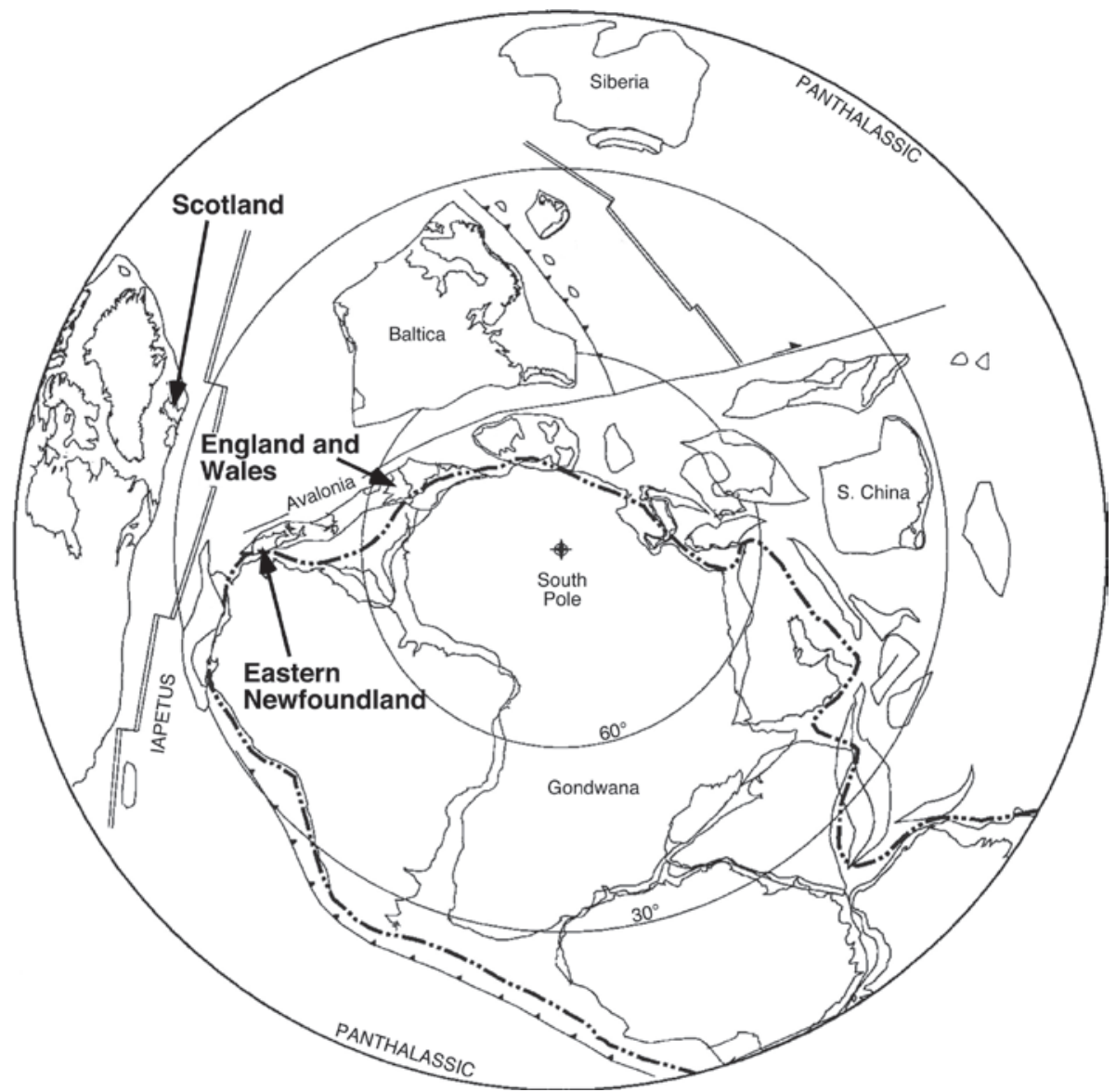

Fig. 4. Palaeogeographical reconstruction of the Furongian showing the relative positions of England and Wales and eastern Newfoundland on the Avalonian continent (after Cocks \& Torsvik, 2002).

and the wall of both processes and vesicle is thin. Although the specimens are corroded, a granular, possibly finely echinate sculpture is visible on many specimens, this being most apparent on the processes. A pronounced conical polar protuberance bearing a single process is present in a small number of specimens. Excystment openings were not observed.

Dimensions. 36 specimens. Vesicle length 20 (28.5) $47 \mu \mathrm{m}$; vesicle breadth 14 (20.5) $25.5 \mu \mathrm{m}$; vesicle breadth: length 57 (74) $100 \%$; maximum process length 13 (20) $37.5 \mu \mathrm{m}$; process length: vesicle length 43 (73) 170\%; total number of processes 9 (12) 16 .

Remarks. The processes of the Comley specimens are considerably longer than those of the Ordovician type material and frequently longer than those of specimens of Cambrian age described by Martin \& Dean (1981), Parsons \& Anderson (2000) and Moczydłowska \& Stockfors (2004). Martin (1973, pl. VIII, fig. 2) illustrates a specimen of $A$. achrasii which appears to display centrally located process insertion and, following Parsons \& Anderson (2000), such forms are herein accommodated within the species. The same illustration also displays a conical polar extension and similar forms, although to some extent displaying the features of genus Tectitheca Burmann, 1968, are otherwise indistinguishable from $A$. achrasii and are also herein included in the species. Some specimens show disparity of vesicle width of the polar regions with a polygonality approaching that of genus Polygonium (Vavrdová, 1966) Moczydłowska \& Stockfors, 2004. Forms encountered in the Comley assemblages otherwise resembling $A$. achrasii but lacking a long axis and with more or less evenly distributed processes are referred to the genus Polygonium. The species Actinotodissus achrasii, Ninadiacrodium caudatum (Vanguestaine, 1973) Raevskaya \& Servais, 2009, Ninadiacrodium aff. caudatum, Dasydiacrodium obsonum Martin in Martin \& Dean, 1988, Scalenadiacrodium comleyense gen. et sp. nov., Ninadiacrodium dumontii (Vanguestaine, 1973) Raevskaya \& Servais, 2009 and Polygonium spp. herein may be closely related biological entities with rather arbitrary distinctions subdividing a morphological continuum. Raevskaya \& Servais (2009) discuss the continuity of morphological variation between $N$. dumontii and $N$. caudatum.

Previous records. Actinotodissus achrasii has been widely reported in Furongian and Lower Ordovician assemblages. The Furongian occurrences are listed here. Furongian, Parabolina spinulosa Zone to Lower Tremadocian (verified by macrofossils), eastern Newfoundland, Canada (Martin \& Dean, 1981, 1988); Furongian, Protopeltura praecursor Zone to Lower Tremadocian (verified by macrofossils), eastern Newfoundland, Canada (Parsons \& Anderson, 2000); Furongian, China (Yin Lei-ming, 


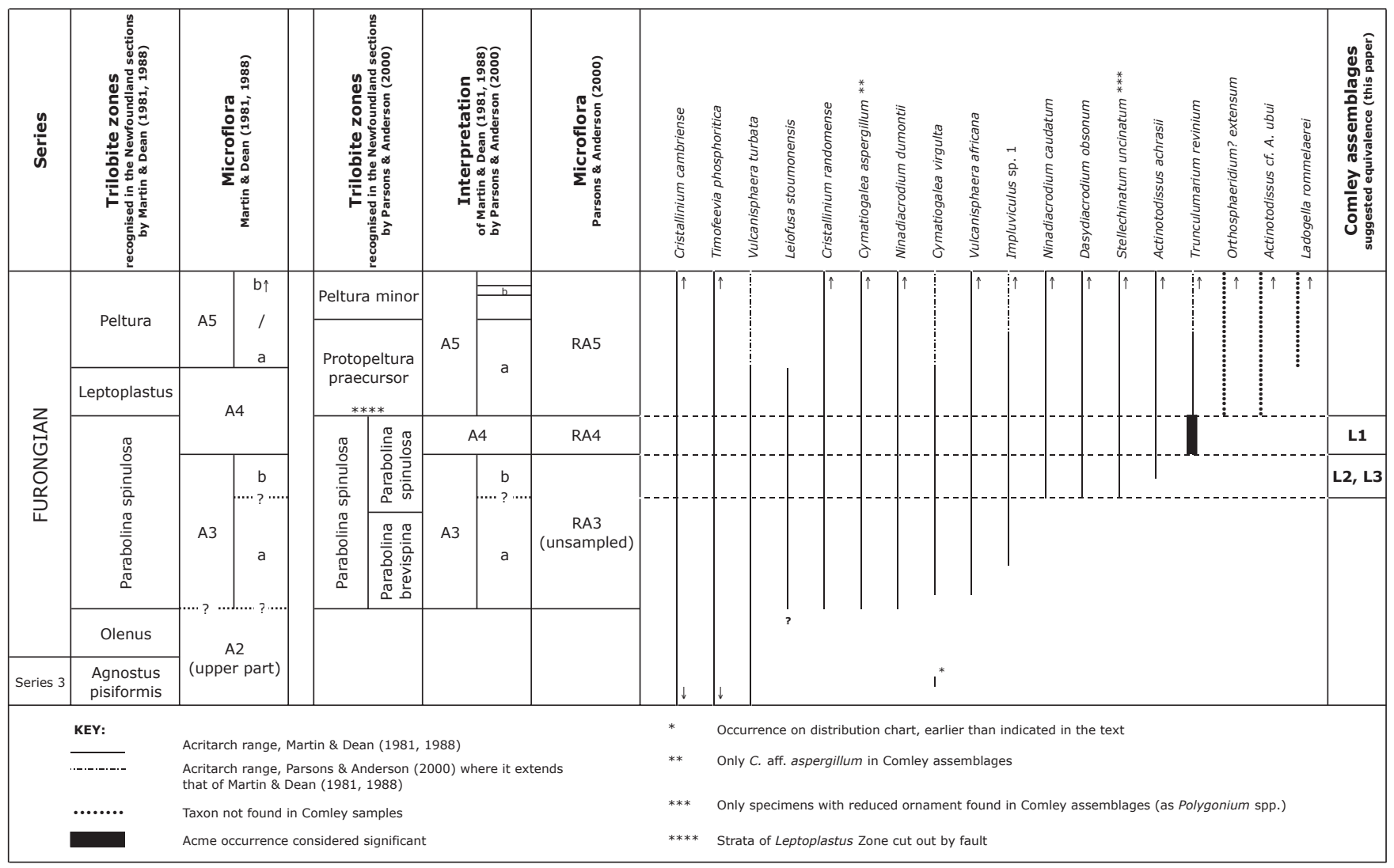

Fig. 5. Ranges of acritarch taxa in eastern Newfoundland given by Martin \& Dean (1981, 1988) and Parsons \& Anderson (2000). Taxa recorded in Comley assemblages unless otherwise indicated.

1986); Furongian, Peltura scarabaeoides Zone (verified by macrofossils), Öland, Sweden (Di Milia et al., 1989); Furongian, Algeria (Vecoli, 1996); Furongian to Tremadocian, Arctic Russia (Moczydłowska \& Stockfors, 2004); Furongian, northern Spain (Albani et al., 2006); Furongian to Tremadocian, Iran (Ghavidelsyooki, 2006; Ghavidel-syooki \& Vecoli, 2008).

Genus Cristallinium Vanguestaine, 1978

Type species. Cristallinium cambriense (Slavíková, 1968) Vanguestaine, 1978

Cristallinium cambriense (Slavíková, 1968) Vanguestaine, 1978 (P1. 5, fig. 6; P1. 7, fig. 11)

1968 Dictyotidium cambriense Slavíková: 201, pl. II, fig. 1, 3 (nomen nudum).

1972 Cymatiosphaera ovillensis Cramer \& Diez de Cramer: 44, pl. 2, figs $4,7,10$.

1978 Cristallinium cambriense (Slavíková, 1968); Vanguestaine: 271, pl. II, figs 16, 17; pl. III, figs 16, 26.

1990 Cristallinium ovillense (Cramer \& Diez de Cramer, 1972);

Fensome et al.: 161.

Dimensions. 21 specimens. Vesicle size 36 (47) $55.5 \mu \mathrm{m}$; field size 14 (20) $24.5 \mu \mathrm{m}$; field number about 14-20; ornament height 1 (1.4) $2.5 \mu \mathrm{m}$.
Previous records. C. cambriense is widely reported from Cambrian, Series 3 to Tremadocian, see Albani et al. (1991), Moczydłowska (1998) and Vecoli (1996, reported as Cristallinium ovillense (Cramer \& Diez de Cramer, 1972) Fensome et al., 1990).

Cristallinium randomense Martin in Martin \& Dean, 1981 (P1. 5, figs 4, 5; Pl. 7, fig. 12)

1981 Cristallinium randomense Martin in Martin \& Dean: 18, pl. 3, figs 2, 10, 17, 24, 26 (non pl. 3, figs 12, 20; pl. 6, fig. 4, 6).

1988 Cristallinium randomense Martin in Martin \& Dean, 1981 emend.; Martin in Martin \& Dean: 36, pl. 13, figs 6, 9, 17 (non pl. 13, figs $1-5,7,8$ ).

Dimensions. 19 specimens. Vesicle size 38.5 (47) $55 \mu \mathrm{m}$; process length 4.5 (5.5) $7 \mu \mathrm{m}$; process length: vesicle size 9 (12) $16 \%$.

Remarks. The species concept employed here is that provided by Vanguestaine (2002) in his review of the taxon.

Previous records. The stratigraphical range of Furongian given in Vanguestaine \& Brück (2008, p. 91) is accepted here. Trilobite-controlled occurrences in eastern Newfoundland (Martin \& Dean, 1981, 1988; Parsons \& Anderson, 2000), with illustrated specimens critically reviewed in Vanguestaine 

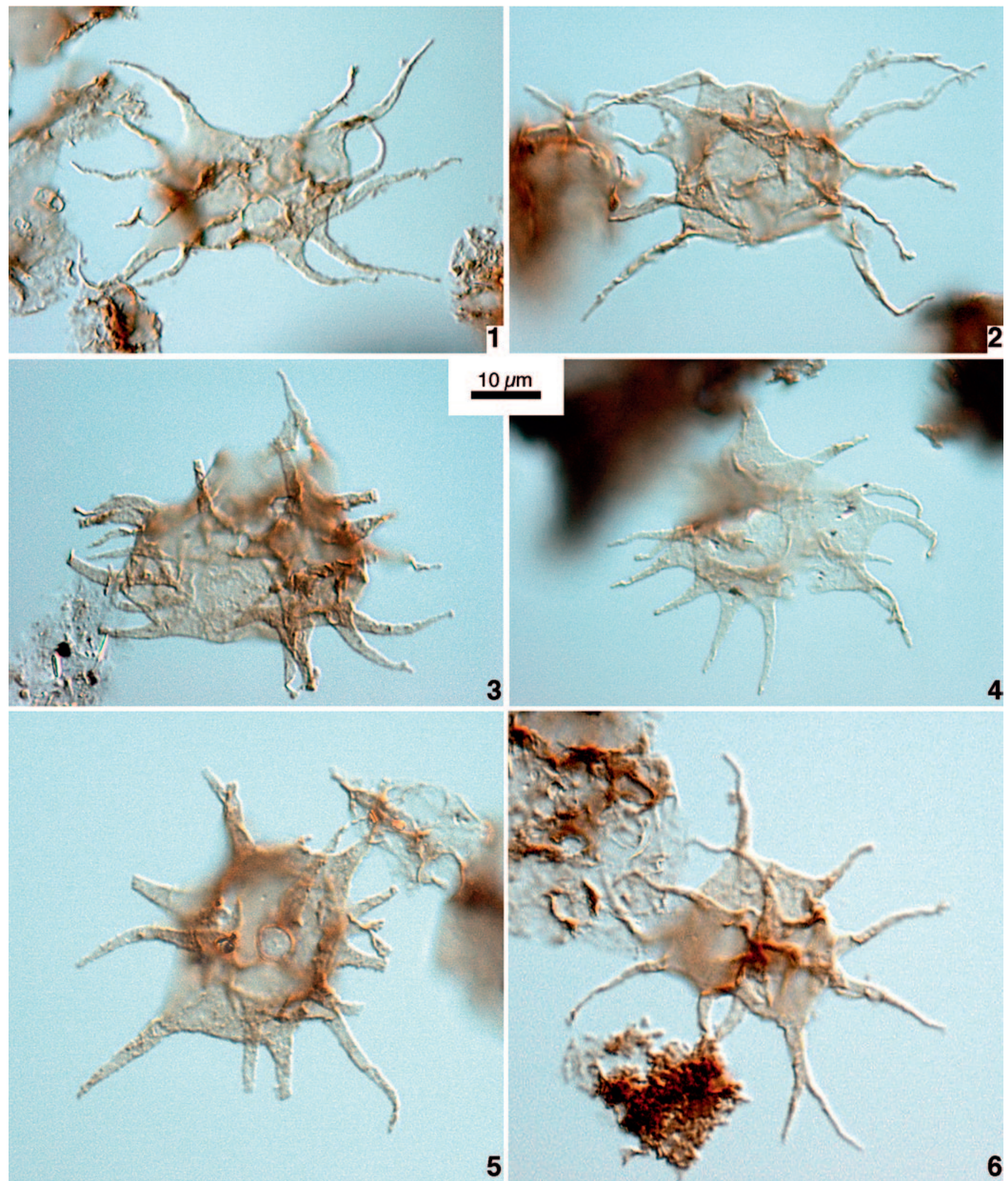

Explanation of Plate 1.

figs 1, 2. Actinotodissus achrasii (Martin, 1973) Yin Lei-ming, 1986: 1, high focus, slide L1a-1 (10 $\mu$ m), K63/0; 2, high focus, slide L1a-1 $(10 \mu \mathrm{m})$, R45/0. figs 3, 4. Dasydiacrodium obsonum Martin in Martin \& Dean, 1988: 3, high focus, slide L2a-1 (10 $\mu \mathrm{m})$, M56/0; 4, high focus, slide L2a-1 (10 $\mu \mathrm{m})$, F63/0. figs 5, 6. Polygonium spp.: 5, high focus, slide L2a-1 (10 $\mu \mathrm{m})$, J63/0; 6, high focus, slide L1a-1 (10 $\mu \mathrm{m}), \mathrm{J} 42 / 2$. 


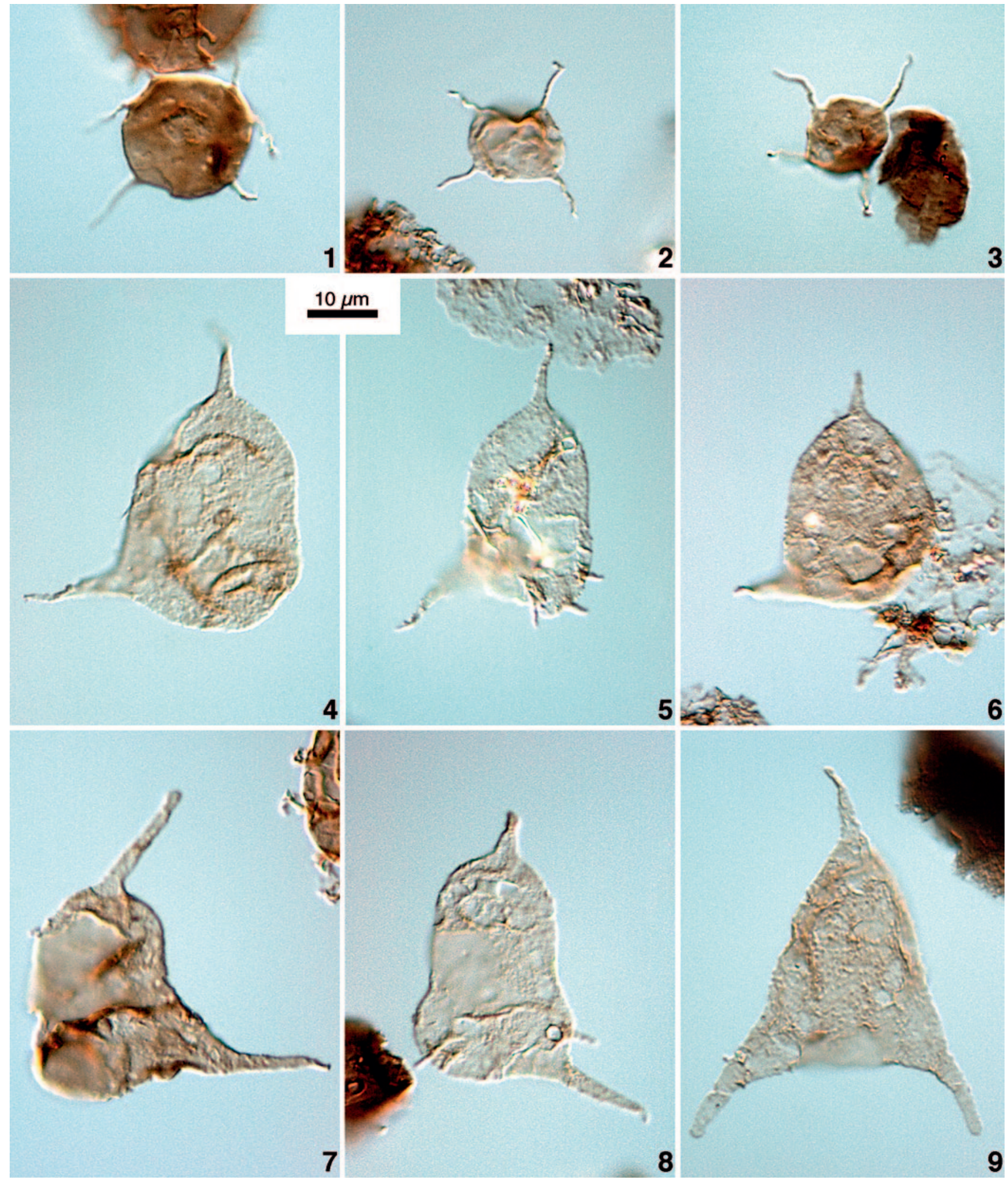

Explanation of Plate 2.

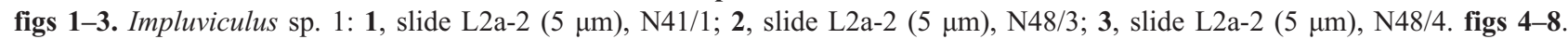
Scalenadiacrodium comleyense gen. et sp. nov.: 4, paratype, slide L3c-1 (10 $\mu \mathrm{m})$, D51/1; 5, slide L3c-2 (5 $\mu \mathrm{m})$, F71/3; 6, slide L2a-2

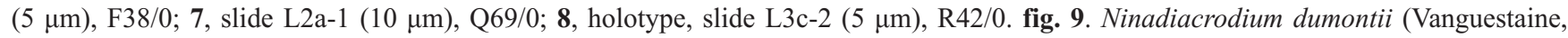
1973) Raevskaya \& Servais, 2009. Slide L2a-1 (10 $\mu \mathrm{m}), \mathrm{P} 46 / 0$. 


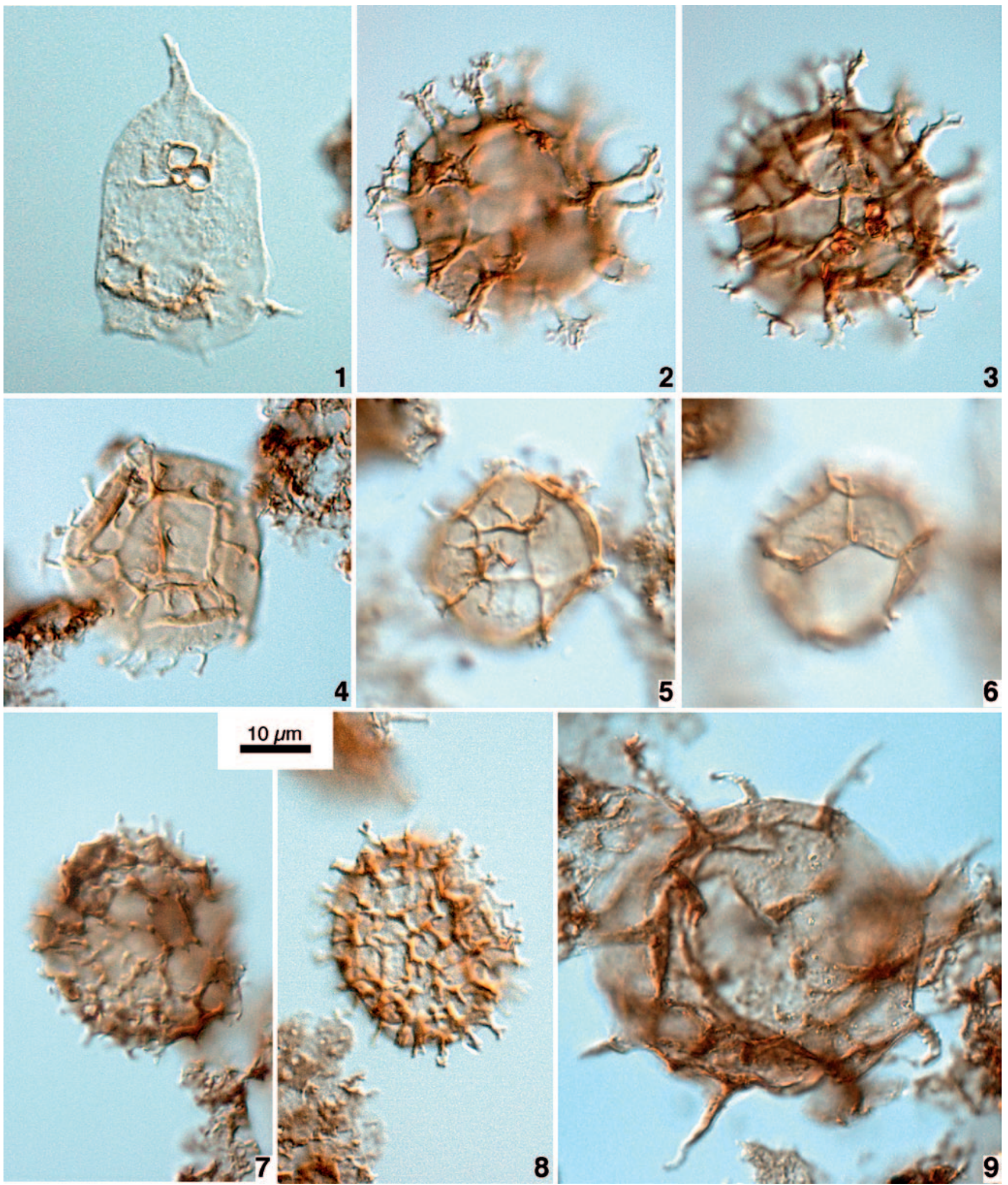

Explanation of Plate 3.

fig. 1. Ninadiacrodium aff. caudatum (Vanguestaine, 1973) Raevskaya \& Servais, 2009. Slide L3c-3 (5 $\mu$ m glycerine jelly), Q32/2. figs 2, 3. Timofeevia phosphoritica Vanguestaine, 1978: 2, high focus, 3, low focus, slide L2a-1 (10 $\mu \mathrm{m})$, L62/0. figs 4-6. Cymatiogalea virgulta Martin in Martin \& Dean, 1988: 4, high focus, slide L1a-1 (10 $\mu \mathrm{m})$, J54/4; 5, high focus, 6, low focus, slide L1a-5 $(10 \mu \mathrm{m})$, D62/3. figs 7, 8. Timofeevia aff. estonica Volkova, 1990: 7, high focus, slide L1a-1 (10 $\mu \mathrm{m})$, J37/0; 8, high focus,

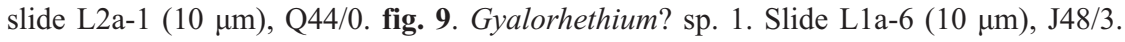




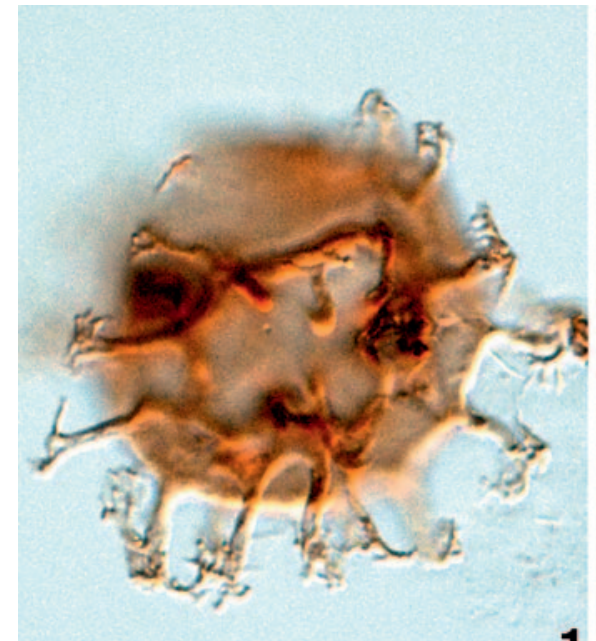

1

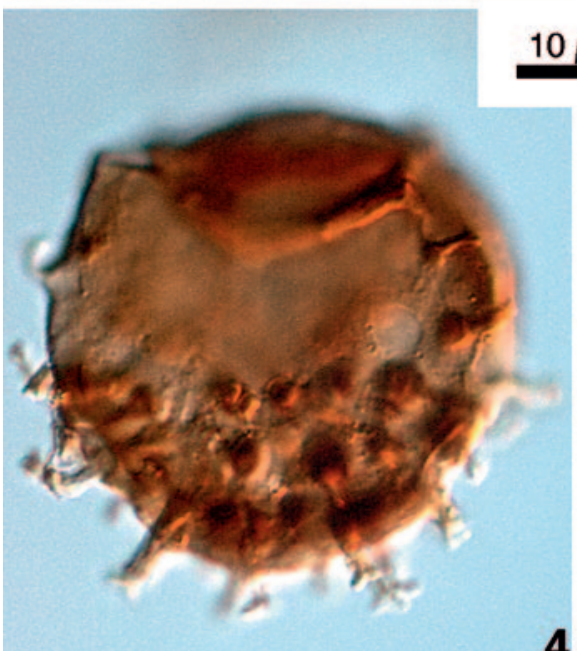

4

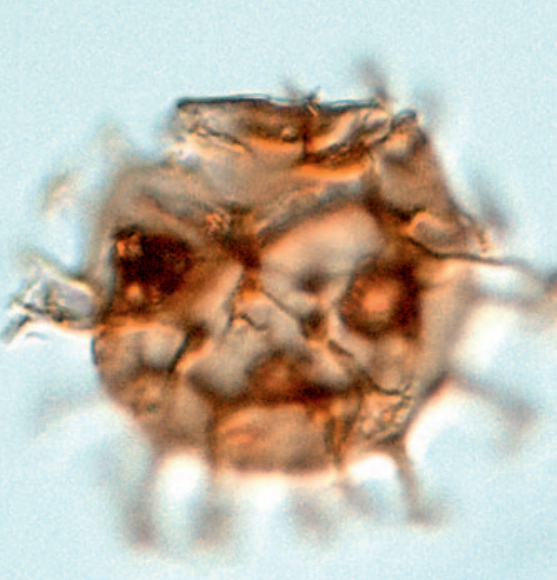

2
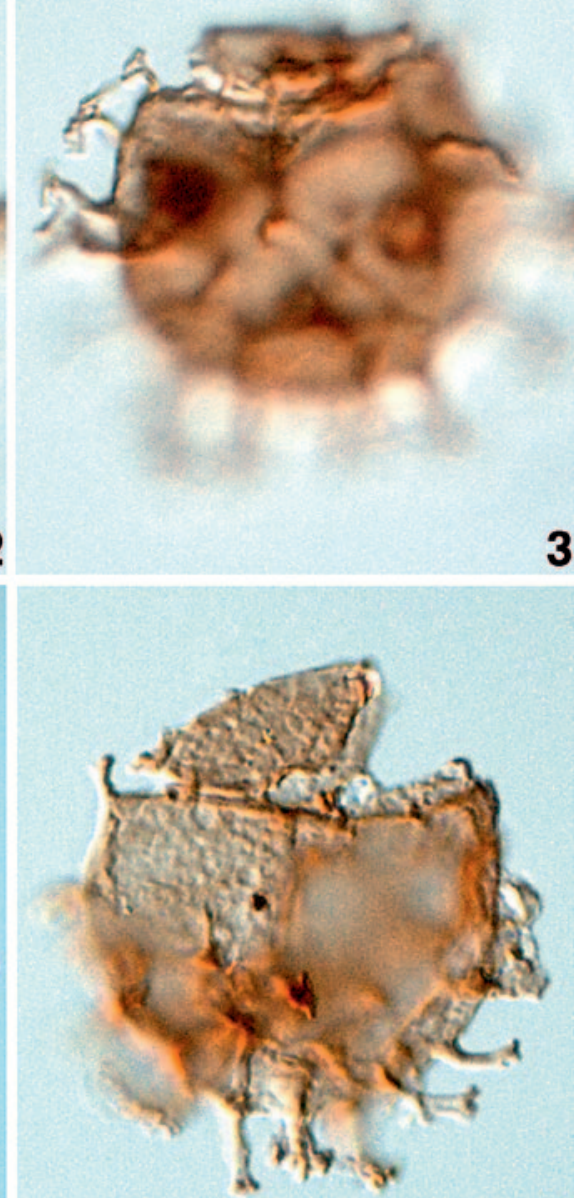

5

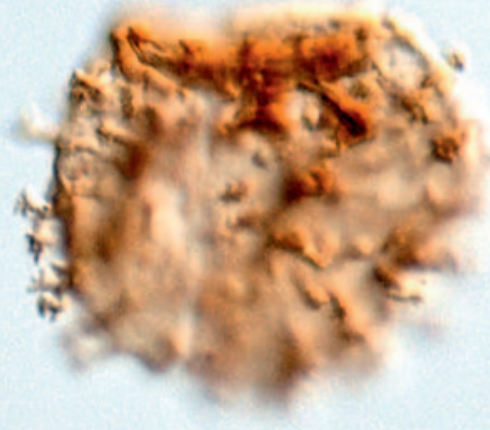

8

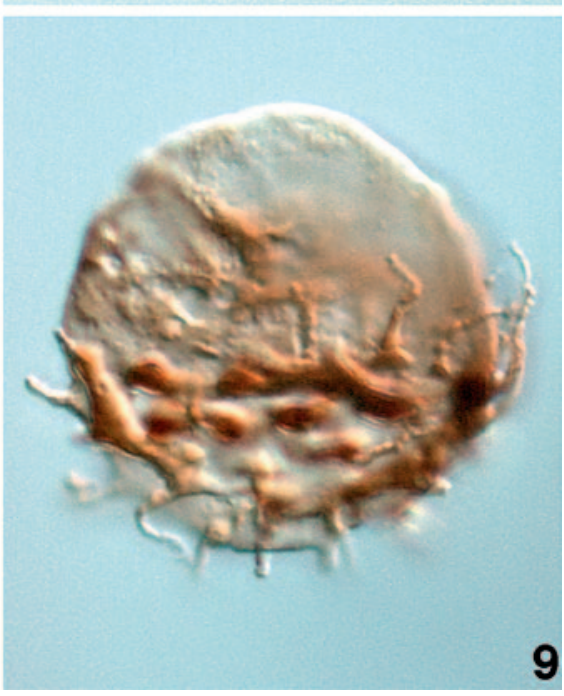

\section{Explanation of Plate 4.}

figs 1-3. Cymatiogalea aff. aspergillum Martin in Martin \& Dean, 1988: 1, high focus, 2, optical section, 3, low focus, slide L2a-1 $(10 \mu \mathrm{m})$, P49/4. figs 4-6. Stelliferidium cortinulamorphum Paalits, 1995: 4, high focus, 5, optical section, slide L3c-1 (10 $\mu \mathrm{m})$, D49/0; 6, high focus, slide L2a-1 (10 $\mathrm{m})$, P41/4. figs 7, 8. Stelliferidium cf. distinctum (Rasul, 1974) Pittau, 1985: 7, high focus, slide L3c-3 (5 $\mu \mathrm{m}$ glycerine jelly), C60/1; 8, high focus, slide L2a-5 (10 $\mu \mathrm{m}), \mathrm{J}$ 48/0. fig. 9. Trunculumarium revinium (Vanguestaine, 1973) Loeblich \& Tappan, 1976. Slide L1a-4 (10 $\mu \mathrm{m}$ glycerine jelly), D54/1. 


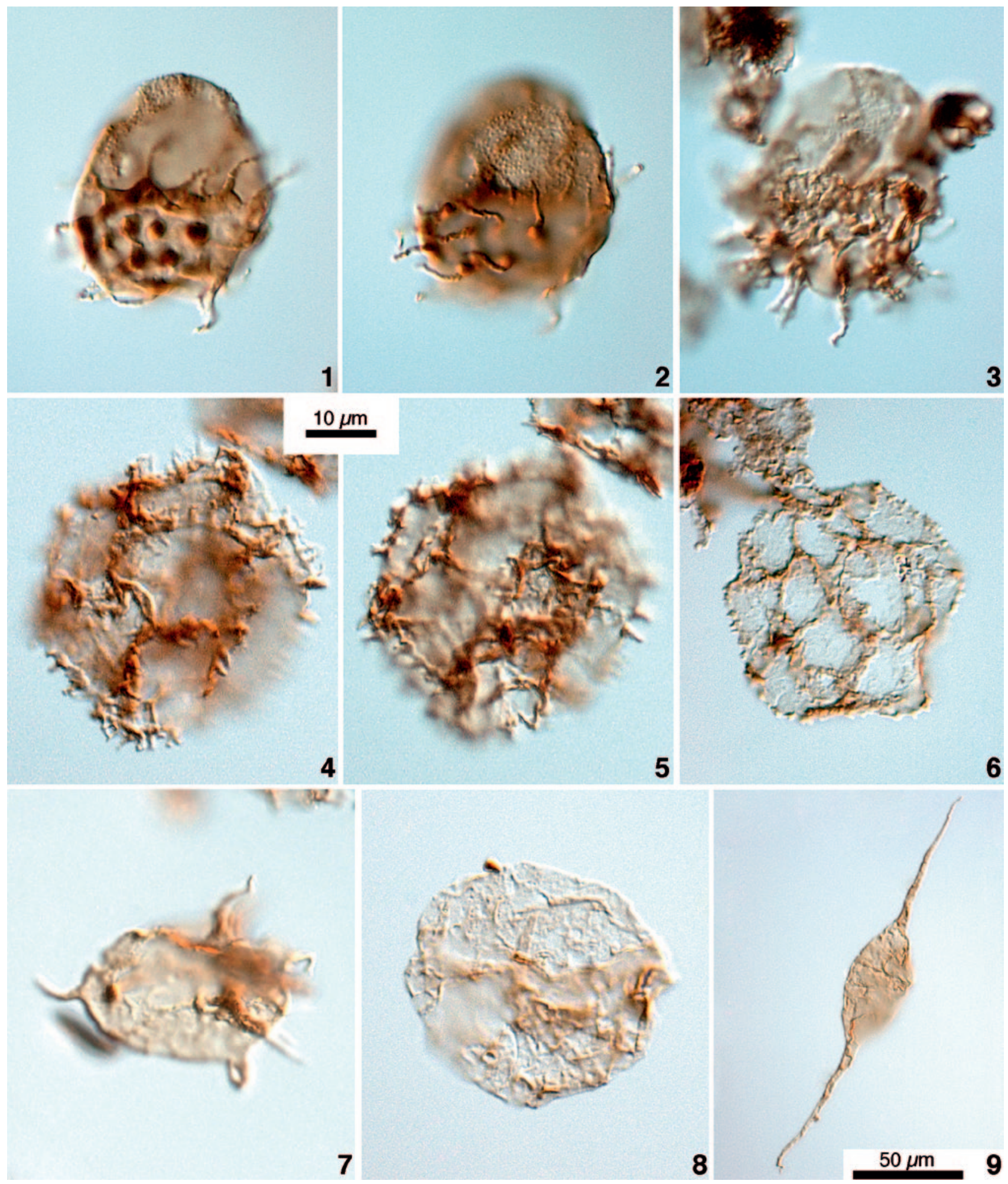

\section{Explanation of Plate 5.}

figs 1-3. Trunculumarium revinium (Vanguestaine, 1973) Loeblich \& Tappan, 1976: 1, high focus, 2, low focus, slide L1a-1 (10 $\mu$ m), H41/0; 3, high focus, slide L1a-1 (10 $\mu \mathrm{m})$, P54/1. figs 4, 5. Cristallinium randomense Martin in Martin \& Dean, 1981: 4, high focus, 5, optical section, slide L1a-1 $(10 \mu \mathrm{m})$, C52/1. fig. 6. Cristallinium cambriense (Slavíková, 1968) Vanguestaine, 1978. High focus, slide L2a-1 (10 $\mu \mathrm{m})$, K58/3. fig. 7. Ninadiacrodium caudatum (Vanguestaine, 1973) Raevskaya \& Servais, 2009. Low focus, slide L1a-5 $(10 \mu \mathrm{m})$, F64/3. fig. 8. Leiosphaeridia sp. Slide L2a-1 $(10 \mu \mathrm{m}), \mathrm{N} 47 / 0$. fig. 9. Leiofusa stoumonensis Vanguestaine, 1973. Slide L2a-5 $(10 \mu \mathrm{m})$, T52/1. Scale bar $10 \mu \mathrm{m}$ in figs $1-8 ; 50 \mu \mathrm{m}$ in fig. 9. 

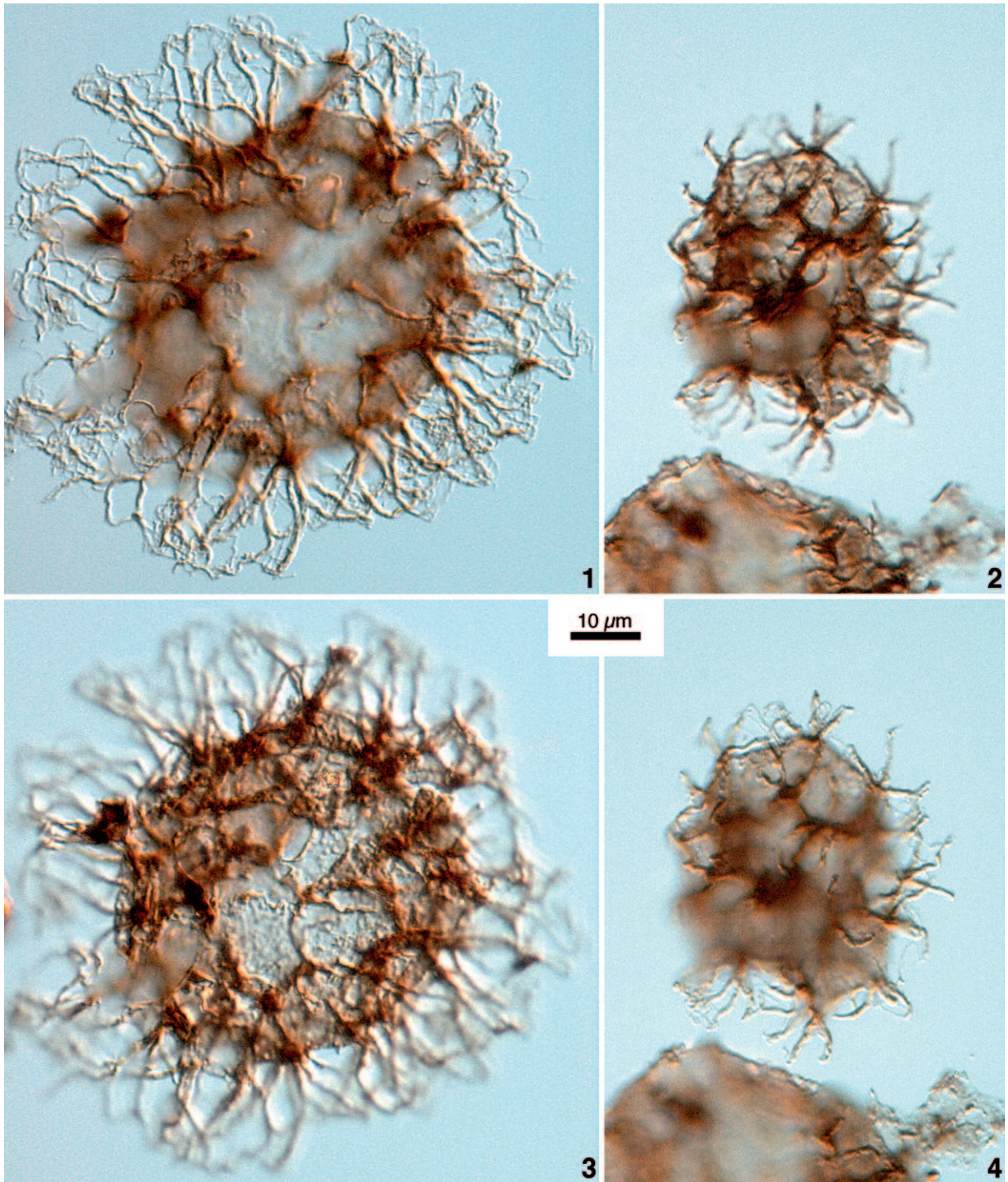

\section{$10 \mu \mathrm{m}$}

3

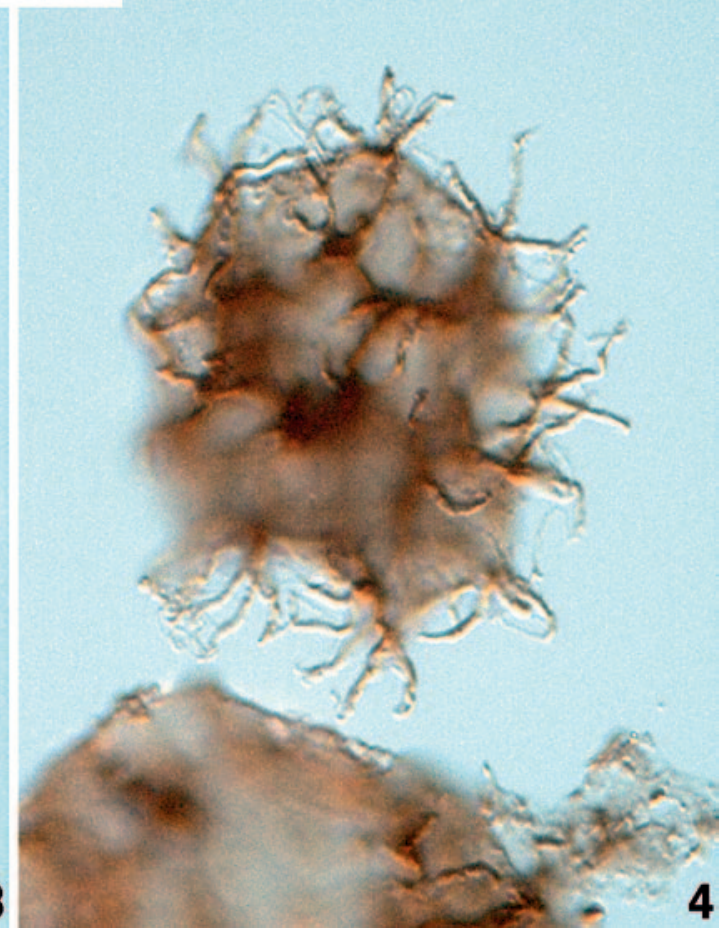

Explanation of Plate 6.

figs 1, 3. Vulcanisphaera africana Deunff, 1961: 1, high focus, 3, lower focus, slide L2a-1 (10 $\mu \mathrm{m}), \mathrm{K} 63 / 0$. figs 2, 4. Vulcanisphaera turbata Martin in Martin \& Dean, 1981: 2, high focus, 4, lower focus, slide L2a-1 (10 $\mu \mathrm{m}), \mathrm{O} 45 / 3$. 


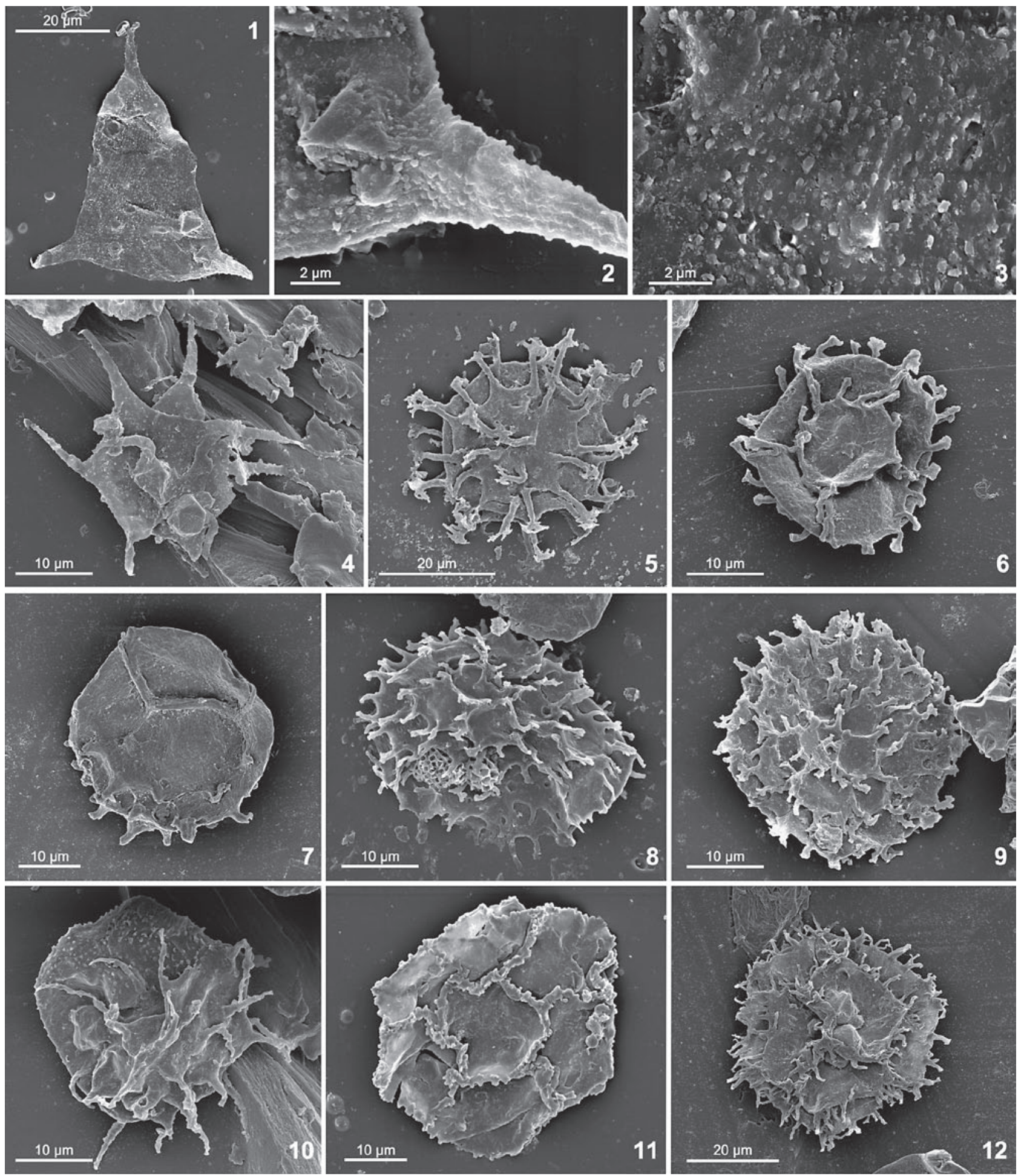

Explanation of Plate 7.

figs 1-3. Ninadiacrodium dumontii (Vanguestaine, 1973) Raevskaya \& Servais, 2009: 2, 3, details of 1; note the arrangement of surface ornament in parallel rows. Specimen from sample L2. fig. 4. Polygonium sp. Specimen from sample L1. fig. 5. Timofeevia phosphoritica Vanguestaine, 1978. Specimen from sample L2. fig. 6. Cymatiogalea virgulta Martin in Martin \& Dean, 1988. Specimen from sample L3. fig. 7. Stelliferidium cortinulamorphum Paalits, 1995. Specimen from sample L3. figs 8, 9. Timofeevia aff. estonica Volkova, 1990: 8, specimen from sample L2; 9, specimen from sample L1. fig. 10. Trunculumarium revinium (Vanguestaine, 1973) Loeblich \& Tappan, 1976. Specimen from sample L1. fig. 11. Cristallinium cambriense (Slavíková, 1968) Vanguestaine, 1978. Specimen from sample L2. fig. 12. Cristallinium randomense Martin in Martin \& Dean, 1981. Specimen from sample L3. 
(2002), indicate a range of Parabolina spinulosa Zone, P. brevispina Subzone (fide Parsons \& Anderson, 2000) to Peltura Zones.

$$
\begin{gathered}
\text { Genus Cymatiogalea Deunff, } 1961 \text { emend. Deunff, Górka \& } \\
\text { Rauscher, } 1974
\end{gathered}
$$

Type species. Cymatiogalea margaritata Deunff, 1961

Cymatiogalea aspergillum Martin in Martin \& Dean, 1988

1988 Cymatiogalea aspergillum Martin in Martin \& Dean: 37, pl. 14, figs $1-7,9$.

Cymatiogalea aff. aspergillum Martin in Martin \& Dean, 1988 (P1. 4, figs 1-3)

Description. The vesicle outline is subcircular to subangular in entire specimens. The thin, smooth to weakly shagreenate wall may or may not be subdivided, wholly or partially into polygonal areas by folds. Excysted specimens usually display notching of the apertural margin. The processes appear to arise at the angles of the polygonal fields and their number varies between individuals. The processes display a variable degree of distal branching, usually to the third order and are shorter around and in the neighbourhood of the apertural margin. The margin is without a differentiated collar but is usually folded in entire specimens. The operculum lacks processes and has a subcircular to subpolygonal outline.

Dimensions. 20 specimens. Vesicle size 24 (32) $43.5 \mu \mathrm{m}$; process length (antapical) 7 (9.5) $13 \mu \mathrm{m}$; process length (antapical): vesicle size 19 (30) 42\%; process length (around aperture) 3.5 (4.5) $5.5 \mu \mathrm{m}$; process length (around aperture): process length (antapical) 33 (48) 65\%; macropyle width (open) 21-41 $\mu \mathrm{m}$; operculum diameter 14-19 $\mu \mathrm{m}$.

Remarks. A number of specimens were recorded conforming with the diagnosis of Cymatiogalea aspergillum with the exception that the membrane connecting the processes was not seen. Membranous fragments were sometimes noted but it was not clear whether these were the remains of lists connecting the processes or of a sheath that may once have surrounded the acritarch. The processes of the Comley specimens may be restricted to the angles of polygonal fields or with intergonal processes also present, whereas only the latter arrangement is indicated in the diagnosis given by Martin (in Martin \& Dean, 1988). In many instances, particularly in cases of poor preservation, it was difficult to distinguish specimens with the operculum in place from specimens of Timofeevia phosphoritica Vanguestaine, 1978. The reduced size of processes in the neighbourhood of the presumed excystment site in the Comley specimens (a feature previously noted in C. aspergillum by Di Milia et al., 1989) could, in suitably preserved specimens, be used to confirm the galeate nature of specimens with the operculum in place. Some of the specimens assigned here to $C$. aff. aspergillum lack clearly defined fields but notching of the apertural margin in dehisced specimens confirms the galeate nature of the vesicle. The degree of prominence of field margins may depend to some degree on the extent of compressional folding at field edges. Cymatiogalea aff. aspergillum differs from C. geometrica Di Milia et al., 1989 in apparently displaying a less regular arrangement of fields and lacking clearly defined lists between the processes.

Previous records. C. aspergillum. Furongian Parabolina spinulosa Zone to Acerocare Zone (verified by macrofossils) eastern Newfoundland, Canada (Martin \& Dean, 1988); Furongian Protopeltura praecursor Zone to Peltura scarabaeoides Zone (verified by macrofossils) eastern Newfoundland, Canada (Parsons \& Anderson, 2000); Furongian Peltura scarabaeoides Zone (verified by macrofossils), Öland, Sweden (Di Milia et al., 1989); Furongian, Belgium (Ribecai \& Vanguestaine, 1993); Furongian, St Tudwal's Peninsula, North Wales (Martin in Young et al., 1994); Furongian, southern Iran (Ghavidel-syooki \& Vecoli, 2008).

\section{Cymatiogalea virgulta Martin in Martin \& Dean, 1988}

(Pl. 3, figs 4-6; P1. 7, fig. 6)

1988 Cymatiogalea virgulta Martin in Martin \& Dean: 38, pl. 14, figs $10,13,14,17$.

1990 Cymatiogalea aff. cristata (Downie, 1958) Rauscher, 1973; Volkova, pl. IX, fig. 14

Description. The vesicle has a subcircular to subangular outline. The thin wall has a surface divided into a small number of polygonal areas by low ridges, possibly folds. The processes are simple, rarely branched, of more or less uniform length and have digitate terminations. In a few cases there are membranous lists connecting the processes. The processes occur both at the angles and along the sides of the polygonal fields. Apertures are rarely present and are formed by the loss of a single polygonal area.

Dimensions. 24 specimens. Vesicle size 24 (30.5) $36.5 \mu \mathrm{m}$; process length 3 (4.5) $6 \mu \mathrm{m}$; process breadth $1 \mu \mathrm{m}$; process length: vesicle size 11 (15) $21 \%$; height of process ramification: total process length 26 (32) 44\%; field size 13 (16) $18.5 \mu \mathrm{m}$; field size: vesicle size 39 (52) $65 \%$.

Remarks. The rarity of delicate translucent membranes connecting processes in the Comley specimens may be a preservational feature. C. virgulta is distinguished from Timofeevia pentagonalis (Vanguestaine, 1974) Vanguestaine, 1978 by having less complex process terminations and in its possession of a macropyle, although the presence of this latter cannot be anticipated in unopened vesicles in the absence of morphological features which would betray its location. Palacios et al. (2009) introduce a new species of a galeate taxon (Stelliferidium albanii) which also lacks any trace of opening structures in the encysted phase, distinguishing it from Timofeevia species on the presence of radiating striations from the process bases and on process shaft morphology. It is beyond the scope of the present investigation to consider the merits of this approach but, as indicated by Palacios et al. (2009), the taxonomy of Furongian specimens of Timofeevia should be reviewed. Such a review should include forms such as $C$. virgulta in its remit. Specimens lacking a macropyle and with slightly more complex process terminations appear transitional to Timofeevia pentagonalis but are included here in $C$. virgulta. It is distinguished from Cymatiogalea wironia Paalits, 1992a by its possession of a greater 
number of polygonal fields including pentagonal and hexagonal forms. The specimen figured as Cymatiogalea aff. cristata by Volkova (1990, pl. IX, fig. 14) closely resembles C. virgulta in the Comley assemblages.

Previous records. Furongian Parabolina spinulosa Zone to Leptoplastus Zone (verified by macrofossils), eastern Newfoundland, Canada (Martin \& Dean, 1988), range extended to the Peltura minor zone by Parsons \& Anderson (2000, not illustrated); (Cymateogalea aff. cristata) Furongian, East European Platform (Volkova 1990); Furongian, Belgium (Ribecai \& Vanguestaine, 1993); Furongian, St Tudwal's Peninsula, North Wales (Martin in Young et al., 1994); Furongian, Algerian Sahara (Vecoli, 1996); Furongian, Asturias, northern Spain (Albani et al., 2006); Furongian, County Wexford, Ireland (Vanguestaine \& Brück, 2008).

Genus Dasydiacrodium Timofeev, 1959

ex and emend. Deflandre \& Deflandre-Rigaud, 1962 emend. Moczydłowska \& Stockfors, 2004

Type species. Dasydiacrodium eichwaldii Timofeev, 1959 ex Deflandre \& Deflandre-Rigaud, 1962

Dasydiacrodium obsonum Martin in Martin \& Dean, 1988 (P1. 1, figs 3, 4)

1988 Dasydiacrodium obsonum Martin in Martin \& Dean: 38, pl. 10 , figs $6,7,10,11,13-15$.

Dimensions. 5 specimens. Vesicle length 25.5 (30) $35 \mu \mathrm{m}$; vesicle breadth 21 (23.5) $27 \mu \mathrm{m}$; process length 10.5 (16.5) $20 \mu \mathrm{m}$.

Remarks. Dasydiacrodium obsonum displays a morphology transitional between that of Ninadiacrodium caudatum and Actinotodissus achrasii. It differs from $N$. caudatum by possessing more numerous processes around its apical pole. It can be distinguished from $A$. achrasii by a disparity in the number of processes between poles and the relatively narrower dimension of one (apical) polar region.

Previous records. Furongian, Parabolina spinulosa Zone to Acerocare Zone (verified by macrofossils), eastern Newfoundland, Canada (Martin \& Dean, 1988); Furongian, North Estonia (Paalits, 1992a); Furongian, Belgium and France (Ribecai \& Vanguestaine, 1993); Furongian, Northeast China (Martin, 1993); Furongian, Algeria (Vecoli, 1996); Furongian, Arctic Russia (Moczydłowska \& Stockfors, 2004); Furongian, northern Spain (Albani et al., 2006); Furongian, Iran (Ghavidel-syooki, 2006; Ghavidel-syooki \& Vecoli, 2008).

\section{Genus Gyalorhethium Loeblich \& Tappan, 1978}

Type species. Gyalorhethium spinuliferum Loeblich \& Tappan, 1978

$$
\text { Gyalorhethium? sp. } 1
$$$$
\text { (P1. 3, fig. 9) }
$$

Description. The vesicle outline is approximately circular, the wall thin with a few broad folds. The processes are simple, hollow and appear to open into the vesicle cavity, tapering gently distally to closed, pointed tips. The processes are widely and evenly spaced, the proximal contacts are angular to slightly curved; the wall is thin. They are of more or less uniform size, one being shorter and thinner. The surface of both vesicle and processes is corroded, but vestiges remain of what was probably an originally granulate or echinate sculpture, slightly more pronounced on the processes.

Dimensions. 3 specimens. Vesicle diameter 48-56 $\mu \mathrm{m}$; process length 14-21 $\mu \mathrm{m}$; process breadth (proximal) 1.5-2 $\mu \mathrm{m}$; process number $17-23$ visible at the vesicle periphery.

Remarks. This form matches the diagnostic criteria of the genus Gyalorhethium although the state of preservation renders identification of the exact nature of the sculptural elements questionable. It lacks a vesicle outline modified by process insertion typical of the genus Polygonium (Vavrdová, 1966) Moczydłowska \& Stockfors, 2004. Gyalorhethium? sp. 1 resembles a specimen illustrated by Parsons \& Anderson (2000, pl. 5, fig. 12) as Baltisphaeridium crinitum Martin in Dean \& Martin, 1978, but has fewer, shorter processes which are open into the vesicle cavity. It also resembles the illustrated specimens of Goniosphaeridium rasulii Welsch, 1986 (Welsch, 1986, pl. 5, figs 9, 10), but possesses a positive sculpture. Gyalorhethium? sp. 1 closely resembles Baltisphaeridium verutum Vecoli, 1996 but has fewer processes and has process cavities apparently in communication with the vesicle cavity. The forms may be conspecific to ?Goniosphaeridium sp. illustrated by Paalits (1992a, pl. 6, fig. 2), but more material will be required for a valid comparison.

\section{Genus Impluviculus Loeblich \& Tappan, 1969 emend. Martin, 1977}

Type species. Impluviculus milonii (Deunff, 1968) Loeblich \& Tappan, 1969

\section{Impluviculus sp. 1}

(Pl. 2, figs 1-3)

1988 Impluviculus sp. A Martin \& Dean: 39, pl. 15, figs 4-6, 10, 11. 2000 Impluviculus sp. cf. I. milonii (Deunff, 1968) Loeblich \& Tappan, 1969; Parsons \& Anderson: 51, pl. 8, figs 7, 9, 10.

Description. The vesicle is circular to rounded subangular in outline, is thin-walled and has a smooth to weakly shagreenate surface. Four to seven simple, hollow, tapering processes with a length approximately $40-60 \%$ of the vesicle diameter are inserted equatorially and in the same plane. The points of insertion are generally not equidistant. The process tips are slightly rounded, the proximal contacts angular and the process cavities appear to be in communication with that of the vesicle. No well defined excystment openings were observed.

Dimensions. 5 specimens. Vesicle diameter $12-20 \mu \mathrm{m}$; process length $8-12 \mu \mathrm{m}$.

Remarks. The small number of specimens recorded here could not be assigned with confidence to any formally described species of Impluviculus. They closely resemble specimens of Impluviculus 
sp. A illustrated in Martin \& Dean (1988) and a specimen of Impluviculus cf. I. milonii in Parsons \& Anderson (2000). There is little to distinguish several species of the genus and the Comley forms resemble I. multiangularis (Umnova in Umnova \& Vanderflit, 1971) Volkova, 1990 but have a less angular outline, I. villosiusculus Volkova, 1990 but lack a finely granular surface ornament and I. cleae (Martin, 1973) Martin, 1977 but lack a prominent ornamented opening.

Previous records. Impluviculus sp. A in Martin \& Dean (1988), Furongian, Parabolina spinulosa Zone to the Peltura Zones (verified by macrofossils), eastern Newfoundland. Impluviculus sp. cf. I. milonii, Furongian, Parabolina spinulosa Zone, P. spinulosa Subzone to Tremadocian (verified by macrofossils), eastern Newfoundland (Parsons \& Anderson, 2000).

Genus Leiofusa (Eisenack, 1938)

Combaz, Lange \& Pansart, 1967

Type species. Leiofusa fusiformis (Eisenack, 1934) Eisenack, 1938

Leiofusa stoumonensis Vanguestaine, 1973

(P1. 5, fig. 9)

1973 Leiofusa stoumonensis Vanguestaine: 29; pl. I, figs 7, 11, 12. 1985 Leiofusa sp. Albani et al.: pl. I, figs 7, 8.

Dimensions. 28 specimens. Vesicle length 36.5 (60.5) $76 \mu \mathrm{m}$; vesicle breadth 15 (26.5) $31.5 \mu \mathrm{m}$; vesicle breadth: length 34 (45) $54 \%$; process length 33 (58) $77 \mu \mathrm{m}$; process length: vesicle length 66 (97) $136 \%$.

Previous records. Furongian, Stavelot, Belgium (Vanguestaine, 1973; Ribecai \& Vanguestaine, 1993); Furongian, Parabolina spinulosa Zone to Leptoplastus Zone (verified by macrofossils), eastern Newfoundland (Martin \& Dean, 1981, 1988); Furongian, Parabolina spinulosa Zone, P. spinulosa Subzone (verified by macrofossils) eastern Newfoundland (Parsons \& Anderson, 2000); Furongian, central Sardinia (Albani et al., 1985; Di Milia, 1991); Furongian, East European Platform (Volkova, 1990; Paalits, 1992a \& b); Furongian, St Tudwal's Peninsula, northwestern Wales (Martin in Young et al., 1994).

Genus Leiosphaeridia Eisenack, 1958 emend.

Downie \& Sarjeant, 1963 emend. Turner, 1984

Type species. Leiosphaeridia baltica Eisenack, 1958

Leiosphaeridia spp.

(Pl. 5, fig. 8)

Dimensions. 43 specimens. Vesicle diameter 28 (56.5) $137 \mu \mathrm{m}$.

Remarks. Most of the specimens have extremely thin wrinkled walls. No attempt has been made herein to identify individual species of the genus Leiosphaeridia.
Genus Ninadiacrodium Raevskaya \& Servais, 2009

Type species. Ninadiacrodium dumontii (Vanguestaine, 1973) Raevskaya \& Servais, 2009.

\section{Ninadiacrodium caudatum (Vanguestaine, 1973) Raevskaya \& Servais, 2009}

(Pl. 5, fig. 7)

1973 Dasydiacrodium caudatum Vanguestaine: 30, pl. 1, figs 9, 13. 2009 Ninadiacrodium caudatum (Vanguestaine, 1973) emend. nov.; Raevskaya \& Servais: 226, pl. 1, figs 1-3; text-fig. 3.

Dimensions. 13 specimens. Vesicle length 23.5 (30) $35 \mu \mathrm{m}$; vesicle breadth 18.5 (23) $29 \mu \mathrm{m}$; apical process length 7 (11.5) 17.5 $\mu \mathrm{m}$; antapical process length 10 (13) $18.5 \mu \mathrm{m}$; antapical process number 7 (9) 11.

Remarks. Ninadiacrodium caudatum is a distinctive and stratigraphically important taxon. To avoid any potential dilution of the specific concept a possibly closely related form encountered in the Comley samples is treated separately below as $N$. aff. caudatum.

Previous records. Furongian, Belgium and France (Vanguestaine, 1973; Ribecai \& Vanguestaine, 1993); Furongian, Parabolina spinulosa Zone to Lower Tremadocian (verified by macrofossils), eastern Newfoundland (Martin \& Dean, 1981, 1988); Furongian, Parabolina spinulosa Zone, P. spinulosa Subzone (verified by macrofossils), eastern Newfoundland (Parsons \& Anderson, 2000); Furongian, East European Platform (Volkova, 1990); Furongian, North Estonia (Paalits, 1992a); Furongian, southern Tunisia (Vecoli, 1999); Furongian, southwestern Sardinia (Ribecai et al., 2005); Furongian, Arctic Russia (Raevskaya \& Servais, 2009).

Ninadiacrodium aff. caudatum (Vanguestaine, 1973) Raevskaya \& Servais, 2009

(Pl. 3, fig. 1)

Description. The vesicle outline is elongated subtriangular to elliptical with a single process at one (apical) pole of the long axis and four to eight processes of variable length clustered around the antapical pole. The wall of both vesicle and processes is thin and bears a finely granular ornament. The processes are mostly hollow with generally angular proximal contacts and taper distally to pointed tips. The process cavity is in communication with that of the vesicle. Some of the smallest processes may be solid. No excystment openings were observed.

Dimensions. 13 specimens. Vesicle length 28 (34.5) $41 \mu \mathrm{m}$; vesicle breadth 21 (25.5) $30.5 \mu \mathrm{m}$; apical process length 4.5 (10) 13 $\mu \mathrm{m}$; antapical process length 3.5 (6) $9.5 \mu \mathrm{m}$; antapical process number 4 (6) 8 .

Remarks. This form is distinguished from Ninadiacrodium caudatum by its more elliptical outline and generally fewer and shorter antapical processes which are often more variable in length. $N$. aff. caudatum differs from Dasydiacrodium setuensis Paalits, $1992 \mathrm{~b}$ in possessing shorter, generally more numerous 
and more variable processes. A small number of specimens were encountered in the Comley assemblages that bear some resemblance to $N$. aff. caudatum but are not described here. Some may be compressed and distorted specimens of Scalenadiacrodium comleyense whilst others may be extreme variants of the Ninadiacrodium/Scalenadiacrodium morphologies formally identified.

Ninadiacrodium dumontii (Vanguestaine, 1973) Raevskaya \& Servais, 2009

(Pl. 2, fig. 9; Pl. 7, figs 1-3)

1973 Veryhachium dumontii Vanguestaine: 28, pl. 1, figs 1, 2, 8. 1992b Veryhachium incus Paalits: 47, pl. 2, fig. 6.

2009 Ninadiacrodium dumontii (Vanguestaine, 1973) emend. nov.; Raevskaya \& Servais: 228, pl. 1, figs 4, 5, 7-12; pl. 2, figs $1-11$; text-fig. 3 .

Dimensions. 16 specimens. Vesicle length 29 (35.5) $44 \mu \mathrm{m}$; vesicle breadth 23.5 (30) $41 \mu \mathrm{m}$; apical process length 7 (10.5) $14.5 \mu \mathrm{m}$; antapical process length 7 (11.5) $15 \mu \mathrm{m}$.

Remarks. Questions concerning the generic assignment of this species are reviewed by Servais et al. (2007) who concluded that the species should be regarded as a diacrodian acritarch. Raevskaya \& Servais (2009) duly proposed the new genus Ninadiacrodium and recombined, with emendation, the species $V$. dumontii Vanguestaine, 1973 as type species. Raevskaya \& Servais (2009) regard Veryhachium incus Paalits, 1992b as a junior synonym of $N$. dumontii, an opinion accepted herein.

Previous records. Furongian, Belgium and France (Vanguestaine, 1973; Ribecai \& Vanguestaine, 1993); Furongian, Parabolina spinulosa Zone to Acerocare Zone, possibly Tremadocian (verified by macrofossils) eastern Newfoundland (Martin \& Dean 1981, 1988); Furongian, Parabolina spinulosa Zone, P. spinulosa Subzone to Acerocare Zone (verified by macrofossils), eastern Newfoundland (Parsons \& Anderson, 2000); Furongian, East European Platform (Volkova, 1990; Paalits, 1992b); Furongian, North and northwestern Estonia (Paalits, 1992a; Mens et al., 1997); Tremadocian (considered reworked), central Sardinia (Di Milia \& Tongiorgi, 1993); Furongian, Algerian Sahara (Vecoli, 1996); Furongian, Arctic Russia (Raevskaya \& Golubkova, 2006; Raevskaya \& Servais, 2009); Furongian, northern Spain (Albani et al., 2006); Furongian, southern Iran (Ghavidel-syooki \& Vecoli, 2008).

\section{Genus Polygonium (Vavrdová, 1966) \\ Moczydłowska \& Stockfors, 2004}

Type species. Polygonium gracile Vavrdová, 1966 emend. Jacobson \& Achab, 1985.

\section{Polygonium spp.}

(P1. 1, figs 5, 6; P1. 7, fig. 4)

Description. The vesicle outline is polygonal being strongly modified by the broad-based processes. The thin wall of both vesicle and processes bears a granulate sculpture variably expressed. The processes are simple, hollow and open into the vesicle cavity, tapering distally to closed pointed tips. No regular openings were observed.

Dimensions. 11 specimens. Vesicle size $22(26.5) 33 \mu \mathrm{m}$; process length 10.5 (17) $24.5 \mu \mathrm{m}$; process breadth $1.5-3.5 \mu \mathrm{m}$; process length: vesicle size 37 (65) 100\%; process number 10 (12) 16 .

Remarks. Specimens assigned to Polygonium spp. lack the prominent echinate ornament of Stellechinatum uncinatum (Downie, 1958) Molyneux, 1987. Specimens included here in Polygonium spp. range from those with a subquadrangular outline but with processes seemingly randomly disposed over the vesicle surface, to those with an essentially subcircular outline strongly modified by the processes. It is possible that some specimens of Actinotodissus achrasii and D. obsonum in polar compression might resemble Polygonium spp. Specimens figured as Stellechinatum or Polygonium sp. and Polygonium sp. in Parsons \& Anderson (2000, pl. 3, figs 5, 6) appear to closely resemble the Comley specimens. Similarly, a specimen figured as Stellichinatum uncinatum (Downie, 1958) Martin in Martin \& Dean $(1988$, pl. 17, figs 14, 15) has a subdued ornament and may resemble the Comley forms.

\section{Genus Scalenadiacrodium gen. nov.}

Type species. Scalenadiacrodium comleyense sp. nov.

Derivation of name. Latin, scalenus = unequal, reflecting the variation in length of the processes on the antapical polar area of this diacromorph genus.

Diagnosis. The vesicle outline is elongate-triangular (isosceloid) with rounded apices. The wall of both vesicle and processes is single-layered, shagreenate or with a finely granular ornament. The process distribution is 'heteropolar'. The antapical pole bears a single, simple, hollow process tapering to a closed, pointed tip. The process cavity freely communicates with the vesicle cavity. A morphologically similar process, of approximately equal or longer length, is located at one of the apices of the antapical pole, arising at an angle to the polar axis. There may be no additional processes or one or a small number of 'secondary' processes, often concentrated in the neighbourhood of the antapical polar angle not bearing the 'primary' process, and often not in the same plane as the two primary processes. The 'secondary' processes are considerably smaller than the 'primary' processes, have a similar morphology to the 'primaries' but may be solid. No excystment opening has been observed.

Comparison. Scalenadiacrodium gen. nov. is distinguished from Ninadiacrodium Raevskaya \& Servais, 2009 by possessing only two as opposed to three or more 'primary' processes, the third angle of the elongate triangular vesicle is either without processes or with one or a small number of 'secondary' processes of considerably smaller size. In most other respects Scalenadiacrodium resembles Ninadiacrodium with which it may have a close phylogenetic relationship. Sylvanidium Loeblich, 1970 resembles Scalenadiacrodium but has a generally 'bean-shaped' vesicle, 'secondary' processes arising uniformly at right angles to the two 'primaries' and a smooth wall (Loeblich, 1970, p. 736). 
Scalenadiacrodium is distinguished from Leiofusa (Eisenack, 1938) Combaz, Lange \& Pansart, 1967 by its elongate triangular outline and from Veryhachium (Deunff, 1954) Turner, 1984 by its possession of only two 'primary' processes.

Remarks. The systematic position of Ninadiacrodium is discussed in detail by Raevskaya \& Servais (2009) and their arguments generally apply to Scalenadiacrodium. The possession of two rather than three 'primary' processes is here considered sufficient for the generic separation, reflecting some morphographical similarities with leiofusid acritarchs. Emending Ninadiacrodium to encompass the elongate triangular forms with two 'primary' processes would represent a major dilution of the original concept.

\section{Scalenadiacrodium comleyense sp. nov.} (P1. 2, figs 4-8)

?1988 Dasydiacrodium caudatum Vanguestaine, 1973; Martin \& Dean: pl. 16, figs 5,8 .

1988 Veryhachium dumontii Vanguestaine, 1973; Martin \& Dean: pl. 16, figs 3, 13, 14 (non pl. 16, figs 2, 7, 10-12, 15-18). 1995 ?Leiofusa sp. Paalits: 89; pl. II, figs 4, 6.

Derivation of name. After the type area, the Comley area, Shropshire, England.

Diagnosis. The compressed vesicle has a rounded, elongatetriangular outline. The wall of the vesicle and processes is thin, single-layered, with a shagreenate to granulate surface. In some instances there is a suggestion of alignment of the granular ornament parallel to the polar axis of the vesicle. Two primary processes of equal or unequal length are always present, one, generally shorter, located at the apex of the vesicle, the other at one of the antapical angles. The primary processes are hollow, have subangular proximal contacts, are open into the vesicle cavity and taper to closed, pointed tips. The antapical process is not aligned with the apical process, but at an angle to and away from the vesicle long axis. One to four secondary processes, considerably smaller than the primary processes, may or may not be present and, whilst generally clustered in the neighbourhood of the third antapical angle of the vesicle, they are often not in the same plane as the primary processes. No definitive excystment openings have been observed.

Holotype. Slide L3c-2 (5 $\mu \mathrm{m})$, England Finder (EF) reference: K34/3 (P1. 2, fig. 8).

Paratype. Slide L3c-1 (10 $\mu \mathrm{m})$, EF ref.: Y25/1 (Pl. 2, fig. 4).

Locality and horizon. Shoot Rough Road Shales, Locality L3, SO 49 NE 4825 9534, Comley, Shropshire, UK.

Dimensions. 28 specimens. Vesicle length 28 (38.5) $47 \mu \mathrm{m}$; vesicle breadth 21 (27.5) $37.5 \mu \mathrm{m}$; 'primary' process length (near broader, antapical, pole of vesicle) 7 (14.5) $23.5 \mu \mathrm{m}$; 'primary' process length (narrower, apical, pole of vesicle) 6 (12) $17.5 \mu \mathrm{m}$; 'secondary' process length (longest of any secondaries present) 2.5 (4) $7 \mu \mathrm{m}$.
Stratigraphic range. Furongian Series, most probably Parabolina spinulosa trilobite Zone.

Comparison. Scalenadiacrodium comleyense is distinguished from Ninadiacrodium dumontii (Vanguestaine, 1973) Raevskaya \& Servais, 2009 by its possession of two rather than three primary processes. S. comleyense resembles Ninadiacrodium caudatum (Vanguestaine, 1973) Raevskaya \& Servais, 2009 but has a different arrangement of antapical processes which are of non-uniform size. Species attributed to the genus Nellia Golub \& Volkova in Volkova \& Golub, 1985 have a more symmetrical subtriangular outline and recurved processes (Volkova \& Golub, 1985). S. comleyense is distinguished from Sylvanidium paucibrachium Loeblich, 1970 by its considerably smaller size, thin wall, surface sculpture and less fusiform vesicle outline, and from Sylvanidium? hawbanense Miller \& Al-Ruwaili, 2007 by the less uniform size and distribution of its processes (Miller \& Al-Ruwaili, 2007). S. comleyense closely resembles several of the specimens figured as Veryhachium dumontii Vanguestaine, 1973 by Martin (in Martin \& Dean, 1988). Specimens of $S$. comleyense which lack secondary processes and with a poorly expressed subtriangular outline resemble Leiofusa cf. L. gravida Pittau, 1985 of Martin in Young et al. (1994) and Leiofusa somniculata Pittau, 1985 (Pittau, 1985, pp. 190-192). However, all specimens attributable to S. comleyense have an asymmetrical vesicle outline tending towards subtriangularity, processes in an angular relationship and frequently more than two processes.

Remarks. This species was informally described by one of the authors in his unpublished $\mathrm{PhD}$ thesis (Potter, University of Sheffield, 1974) under the name Leiofusa scalenabullata, although the possible presence of secondary processes was not included. It was subsequently compared with ?Leiofusa sp. in the Furongian Ulgase Formation of Estonia by Paalits (1995). He also reports that a similar species was found by M. G. Parsons in sequences assigned to the lower and middle parts of the spinulosa Zone in Newfoundland (Paalits, 1995, p. 89). Care must be exercised in distinguishing $S$. comleyense from damaged specimens of $N$. dumontii from which the second 'primary' antapical process has been lost.

Previous records. Veryhachium dumontii Vanguestaine, 1973 in Martin \& Dean, 1988, pl. 16, figs 3, 13, 14, Furongian, Parabolina spinulosa Zone (verified by macrofossils), eastern Newfoundland, Canada (Martin \& Dean, 1988); ?Leiofusa sp. in Paalits, 1995, p. 89; pl. II, figs 4, 6, Furongian, North Estonia (Paalits, 1995).

\section{Genus Stelliferidium Deunff et al., 1974}

Type species. Stelliferidium striatulum (Vavrdová, 1966) Deunff et al., 1974

Stelliferidium cortinulamorphum Paalits, 1995

(P1. 4, figs 4-6; P1. 7, fig. 7)

1990 Stelliferidium aff. S. cortinulum (Deunff, 1961) emend. Deunff et al., 1974; Volkova: 82, pl. II, figs 16, 17, 19. 
?1991 Stelliferidium sp. cf. S. cortinulum (Deunff, 1961) Deunff et al., 1974; Di Milia: pl. 2, fig. 12.

1992b Stelliferidium sp. Paalits: pl. 1, fig. 7.

1995 Stelliferidium cortinulamorphum Paalits: 93, pl. III, figs 2, 3,5 .

Description. The vesicle outline is circular in polar view, with a flattened apical area in lateral view in specimens with the operculum detached. The vesicle wall is about $1 \mu \mathrm{m}$ thick with a shagreenate surface and there is a suggestion in some specimens of faint striae radiating from the process bases. The processes, numbering about 25 to 30 , have brief conical bases, more or less cylindrical shafts with short, very briefly bifurcate or trifurcate terminations, the pinnae having rounded tips. The processes are apparently solid or thick-walled with a narrow cavity apparently not in communication with the vesicle cavity and are mostly concentrated on the antapical hemisphere where they appear to be distributed without regular arrangement. Membranous fragments are sometimes attached to the processes, being the remnants of lists or possibly an enclosing sheath. A few short processes are usually present on the apical hemisphere, in several rows perpendicular to the aperture margin, reflecting a tabulation. Processes or corroded vestiges thereof may occur around the aperture and the apertural margin of open specimens may be notched, further suggesting tabulation. A low collarette with a subpolygonal outline may be present, most marked in specimens with the operculum in place.

Dimensions. 19 specimens. Vesicle diameter (equatorial) 29 (34) $39 \mu \mathrm{m}$; process length (antapical) 8 (9) $10.5 \mu \mathrm{m}$; process breadth 1.5-2 $\mu \mathrm{m}$; process length: vesicle diameter 23 (27) $31 \%$; length of process terminal structure: total process length 17 (22) $31 \%$; diameter of operculum 18 (21) $25 \mu \mathrm{m}$.

Remarks. The specimens encountered in the Comley assemblages match the original diagnosis with the exceptions that the processes are longer (average length $9 \mu \mathrm{m}$ as opposed to $6.5 \mu \mathrm{m}$ ), the opercular diameter is less variable and the vesicle surface is shagreenate rather than rugulate. This last difference may be at least in part due to conditions of preservation. In some specimens, the presence of processes on the apical hemisphere could not be firmly established. Such specimens are included here in S. cortinulamorphum on the basis that this is probably a result of poor preservation. Paalits (1995) pointed out that S. cortinulamorphum displays features of both the genera Cymatiogalea (Deunff, 1961) Deunff et al., 1974 and Stelliferidium, suggesting that it may be an intermediate form. Servais \& Eiserhardt (1995) and Stricanne \& Servais (2002) discuss the complex, unstable taxonomy of the galeate acritarchs. This instability may have resulted in a confused taxonomy and it is possible that specimens in the Furongian assigned to such taxa as Cymatiogalea bellicosa Deunff, 1961, Cymatiogalea cylindrata Rasul, 1974 and Stelliferidium cortinulum (Deunff, 1961) Deunff et al., 1974 may be conspecific with Stelliferidium cortinulamorphum.

Previous records. Furongian, Pskov Region, Russia (Paalits, 1992b); Furongian, North Estonia (Paalits, 1995); S. aff. cortinulum, Furongian to Tremadocian, East European Platform (Volkova, 1990).

Stelliferidium distinctum (Rasul, 1974) Pittau, 1985
1974 Priscogalea distincta Rasul: 50; pl. 4, fig. 1; pl. 7, fig. 3. 1985 Stelliferidium distinctum (Rasul, 1974); Pittau: 194 (non pl. 8, fig. 7).

Stelliferidium cf. distinctum (Rasul, 1974) Pittau, 1985 (P1. 4, figs 7, 8)

?2000 Stelliferidium sp. B Parsons \& Anderson: 67, pl. 12, figs 10-12.

Description. The vesicle outline is circular in polar view, with a flattened apical area in lateral view when the operculum is missing. The wall varies in thickness between specimens and has a smooth to shagreenate surface. The processes are well separated, of more or less uniform size and are evenly distributed on the vesicle surface including the apertural margin but excluding the operculum. A low collar surrounding the macropyle is visible in some specimens. Opercula, when observed in place, have a diameter of about $14 \mu \mathrm{m}$ to $19 \mu \mathrm{m}$. In one case an operculum was observed fallen inside a vesicle, having a more or less circular outline and a diameter of $21 \mu \mathrm{m}$. It is probable that the rim of the operculum is folded together with the apertural margin of the vesicle, resulting in a prominent collar and in an apparently reduced opercular diameter. The processes, in the order of 40 to 60 , have conical bases with cylindrical to slightly tapering shafts, are mainly simple or with a single brief bifurcation or trifurcation and have terminations being divided into a number of brief, rounded pinnae. The processes appear generally solid but may, in some cases, be thickwalled with a narrow cavity. In the latter case it is not clear whether the process and vesicle cavities are in communication. In some cases, variably developed striae radiate from the bases of the processes; their absence in others may be due to poor preservation.

Dimensions. 19 specimens. Vesicle size (equatorial) 29 (34.5) 42 $\mu \mathrm{m}$; process length 3.5 (4.5) $6.5 \mu \mathrm{m}$; process breadth 0.5 (1) 1.5 $\mu \mathrm{m}$; process separation 2.5 (3) $4.5 \mu \mathrm{m}$; process length: vesicle size (equatorial) 10 (13) 18\%; wall thickness 0.5 (1) $2.5 \mu \mathrm{m}$.

Remarks. The specimens were insufficiently well preserved for precise determination but closely resemble Stelliferidium distinctum. The process style matches that shown by Rasul (1974, pl. 7, fig. 3) but may be less complex than that described by Rasul and illustrated on the holotype. The processes may, in some cases, possess a narrow cavity, a feature not mentioned by Rasul. Stelliferidium sp. B in Parsons \& Anderson (2000) closely resembles the Comley form, the clearly hollow nature of the processes and presence of a fragmentary list on some specimens of Stelliferidium sp. B may merely be a symptom of superior preservation. The Comley specimens also resemble Priscogalea chevronensis Vanguestaine, 1974 but may have more numerous processes with less complex process terminations, and a vesicle wall which is shagreenate rather than possessing an ornament of granules. They also resemble Stelliferidium simplex (Deunff, 1961) Deunff et al., 1974 but may possess thicker-walled processes with more complex process terminations. The Comley specimens differ from Stelliferidium pingiculum Martin in Martin \& Dean, 1988 in lacking striate, spinose processes and from Stelliferidium sp. A of Parsons \& Anderson (2000) in possessing considerably fewer processes. 
Previous records. Stelliferidium distinctum, Tremadocian, Shropshire, England (Rasul, 1974).

\section{Genus Timofeevia Vanguestaine, 1978}

Type species. Timofeevia lancarae (Cramer \& Diez de Cramer, 1972) Vanguestaine, 1978

Timofeevia estonica Volkova, 1990

1990 Timofeevia estonica Volkova: 84, pl. IX, figs 4, 5.

Timofeevia aff. estonica Volkova, 1990

(P1. 3, figs 7, 8; P1. 7, figs 8, 9)

Description. The vesicle outline is circular to subcircular, its surface divided by low ridges into numerous polygonal fields, about $40-60$, or possibly more. The ridges probably comprise folds of the vesicle wall along lines of weakness. The folds, and the polygonal fields they help define, are not always uniformly expressed and may in some specimens be absent. The vesicle wall is thin and has a smooth to shagreenate surface. Processes are located at the angles of the polygonal fields and occasionally intergonal processes may be present. The processes are short with angular proximal contacts and taper slightly to blunt or briefly furcate tips. Whether the processes are solid or hollow is unclear. A large opening may be present resulting from the loss of several polygonal plates.

Dimensions. 20 specimens. Vesicle diameter 25.5 (31) $37.5 \mu \mathrm{m}$; polygonal field size 4.5 (6) $7.5 \mu \mathrm{m}$; process length 2.5 (3) 3.5 $\mu \mathrm{m}$; process length: vesicle diameter 7 (10) $13 \%$.

Remarks. Timofeevia aff. estonica differs from T. estonica Volkova, 1990 in lacking the consistent presence of intergonal processes and in possessing less complex process terminations. The latter feature may, to some extent, be a preservational artefact. Timofeevia aff. estonica has shorter processes with less complex distal terminations than those of Timofeevia manata Albani et al., 1991.

Previous records. Timofeevia estonica, Furongian, Estonia (Volkova, 1990); Furongian, North Estonia (Paalits, 1992a); Furongian, Belgium and France (Ribecai \& Vanguestaine, 1993); Furongian, Parabolina spinulosa Zone, P. spinulosa Subzone (verified by macrofossils), eastern Newfoundland (Parsons \& Anderson, 2000).

Timofeevia phosphoritica Vanguestaine, 1978

(Pl. 3, figs 2, 3; Pl. 7, fig. 5)

1959 Archaeohystrichosphaeridium ianischewskyi Timofeev: 33, pl. 3, fig. 2 (nomen nudum).

1959 Archaeohystrichosphaeridium minor Timofeev: 33, pl. 3 fig. 3 (nomen nudum).

1976 Cymatiogalea ianischewski (Timofeev, 1959); Vavrdová: 60. 1976 Cymatiogalea minor (Timofeev, 1959); Vavrdová: 60.

1978 Timofeevia phosphoritica Vanguestaine: 272, pl. III, figs 1-8, 10-12; text-fig. 11.

Dimensions. 19 specimens. Vesicle diameter 27 (32.5) $37 \mu \mathrm{m}$; process length 7 (9) $13 \mu \mathrm{m}$; process length: vesicle diameter 19 (28)
37\%; field size 7 (10) $13 \mu \mathrm{m}$; field size: vesicle diameter 22 (30) $36 \%$; process ramification length: total process length 33 (40) $53 \%$.

Remarks. The specimens encountered here conform to the diagnosis except that the processes are generally longer. The process terminations are less complex than those of Timofeevia lancarae (Cramer \& Diez de Cramer, 1972) Vanguestaine, 1978 and the overall process length shorter but the distinction between endmembers of the two species appears arbitrary.

Previous records. T. phosphoritica is widely reported in assemblages of Cambrian Series 3 to Tremadocian age, see Vecoli (1996), who also notes that the Tremadocian records have been interpreted as reworked.

\section{Genus Trunculumarium Loeblich \& Tappan, 1976}

Type species. Trunculumarium revinium (Vanguestaine, 1973) Loeblich \& Tappan, 1976

Trunculumarium revinium (Vanguestaine, 1973) Loeblich \& Tappan, 1976

(Pl. 4, fig. 9; Pl. 5, figs 1-3; Pl. 7, fig. 10)

1973 Ooidium revinium Vanguestaine: 30, pl. 1, figs 3, 4, 5, 6, $10,14$.

1976 Trunculumarium revinium (Vanguestaine, 1973); Loeblich \& Tappan: 305.

Dimensions. 33 specimens. Vesicle length 27 (36) $44.5 \mu \mathrm{m}$; vesicle breadth 22 (28.5) $36.5 \mu \mathrm{m}$; vesicle breadth: length 70 (79) $89 \%$; process length 7 (11.5) $16.5 \mu \mathrm{m}$; process length: vesicle length 22 (32) $44 \%$.

Remarks. T. revinium has a distinctive morphology and occurs in quantity over a limited stratigraphical range.

Previous records. Furongian, Belgium and France (Vanguestaine, 1973, 1974; Ribecai \& Vanguestaine, 1993); Furongian, Parabolina spinulosa Zone (base and acme) to Peltura Zones (verified by macrofossils), eastern Newfoundland (Martin \& Dean, 1981, 1988); Furongian, Parabolina spinulosa Zone, P. spinulosa Subzone (base and acme) to Acerocare Zone (verified by macrofossils) eastern Newfoundland (Parsons \& Anderson, 2000); Furongian, north Norway (Welsch, 1986); Furongian, East European Platform (Volkova, 1990); Furongian, North Estonia (Paalits, 1992a); Furongian, Poland (Szczepanik, 2001); Furongian, southern Iran (Ghavidel-syooki \& Vecoli, 2008).

Genus Vulcanisphaera Deunff, 1961 emend. Rasul, 1976

Type species. Vulcanisphaera africana Deunff, 1961.

Vulcanisphaera africana Deunff, 1961

(Pl. 6, figs 1, 3)

1958 Hystrichosphaeridium Downie: 340, pl. 16, fig. 10.

1961 Vulcanisphaera africana Deunff: 42, pl. 2, fig. 1, 2.

1976 Vulcanisphaera cirrita Rasul: 480, pl. 1, fig. 3; text-figs 1, 2. 
Dimensions. 12 specimens. Vesicle diameter 43.5 (51) $62 \mu \mathrm{m}$; process length $15(20.5) 24.5 \mu \mathrm{m}$; process length: vesicle diameter 28 (40) $54 \%$.

Remarks. Three species of the genus Vulcanisphaera appear to differ mainly in quantitative rather than qualitative terms. V. africana differs from $V$. cirrita Rasul, 1976 only by possessing generally shorter processes with possibly less extensive distal ramifications, and from $V$. turbata Martin in Martin \& Dean, 1981 in having usually longer processes, lacking a prominently granular vesicle wall and possibly possessing more complex process distal terminations. Both $V$. africana and $V$. turbata display a vesicle wall divided into polygonal fields (Martin in Martin \& Dean, 1988, p. 43) and it is probable that weakly expressed polygonal fields are present in $V$. cirrita. The granular ornament may not be a consistently expressed feature of $V$. turbata and transitional forms between $V$. turbata and $V$. africana are recorded (Martin \& Dean, 1988). The specimens recorded here as $V$. africana match the diagnosis of both $V$. africana and $V$. cirrita. They mainly bear the complex filamentous process terminations of the latter, and display a vesicle wall divided into polygonal fields, a feature most clearly observed in fragmented examples. Martin (in Martin \& Dean, 1981) and Vecoli (1996) regard V. cirrita as a junior synonym of $V$. africana. The distinction between $V$. africana and $V$. turbata is maintained here partly on utilitarian grounds. The forms with relatively short processes and often with a granular vesicle surface ornament make their first appearance earlier in the Cambrian than V. africana (Martin \& Dean, 1981). Most of the relatively subtle distinctions between $V$. turbata and $V$. africana summarized by Martin (in Martin \& Dean, 1988, p. 43) cannot be recognized in the Comley material due to condition of preservation. Specimens of Vulcanisphaera with a granulate wall sculpture and those with relatively short processes are here assigned to $V$. turbata.

Previous records. $V$. africana is widely distributed in the Furongian and Tremadocian, references to Cambrian records are listed here. Furongian, Parabolina spinulosa Zone to Tremadocian (verified by macrofossils), eastern Newfoundland, Canada (Martin \& Dean, 1981, 1988); Furongian, Protopeltura praecursor Zone to Tremadocian (verified by macrofossils), eastern Newfoundland, Canada (Parsons \& Anderson, 2000); Furongian to Tremadocian, north Norway (Welsch, 1986); Furongian, Peltura scarabaeoides Zone (verified by macrofossils), Sweden (Di Milia et al., 1989; Tongiorgi \& Ribecai, 1990); Furongian, Belgium and northern France (Ribecai \& Vanguestaine, 1993); Furongian to Tremadocian, Algerian Sahara (Vecoli, 1996); Furongian, Poland (Szczepanik, 1997; Żylińska et al. 2006); Furongian to Tremadocian, northwest Argentina (Rubenstein et al., 2003; Aráoz \& Vergel, 2006); Furongian, southwestern Sardinia (Ribecai et al., 2005); FurongianTremadocian, southern Iran (Ghavidel-syooki \& Vecoli, 2008).

Vulcanisphaera turbata Martin in Martin \& Dean, 1981 (P1. 6, figs 2, 4)

1981 Vulcanisphaera turbata Martin in Martin \& Dean: 23, pl. 1, figs $2-4$; text-fig. 6.

1990 Raphesphaera turbata (Martin, 1981); Volkova: 80, pl. VI, figs $1-4,6-8$.
Dimensions. 7 specimens. Vesicle diameter 40 (48) $54 \mu \mathrm{m}$; process length 11.5 (15.5) $21 \mu \mathrm{m}$; process length: vesicle diameter 26 (32) $40 \%$.

Remarks. For remarks, see under $V$. africana, above.

Previous records. ?Series 3 to Furongian, ?Lejopyge laevigata Zone to Leptoplastus Zone (verified by macrofossils), eastern Newfoundland (Martin \& Dean, 1981, 1988), range extended to the Peltura minor Zone by Parsons \& Anderson (2000, not illustrated); Furongian, Sardinia (Albani et al., 1985; Di Milia, 1991); Series 3 to Furongian, north Norway (Welsch, 1986); ?Series 3/ Furongian, USA (Wood \& Stephenson, 1989); Raphesphaera turbata, Series 3 to Tremadocian, East European Platform (Volkova, 1990); Furongian, Libya and southern Tunisia (Albani et al., 1991; Tawadros et al., 2001); Furongian, western Russia (Paalits, 1992b); Furongian, North Estonia (Paalits, 1992a); Series 3 to Furongian, Belgium and France (Ribecai \& Vanguestaine, 1993); Series 3 to Furongian, northwestern Wales (Martin in Young et al., 1994); Furongian, northern Spain (Albani et al., 2006); Furongian, probably Olenus/Homagnostus obesus Zone, Olenus scanicus Subzone/Parabolina spinulosa Zone, P. brevispina Subzone (in association with macrofossils), Poland (Żylińska et al., 2006); Guzhangian to Furongian, Iran (Ghavidel-syooki, 2006; Ghavidel-syooki \& Vecoli, 2008); ?Series 3/Furongian, southeastern Ireland (Vanguestaine \& Brück, 2008).

\section{COMLEY ACRITARCH ASSEMBLAGES}

The Comley assemblages are numerically rich and taxonomically diverse. The species composition and approximate relative proportion of each taxon are given in Table 1. The samples yielded generally well-preserved assemblages. Sample L1 is particularly rich in amorphous organic matter.

Cymatiogalea virgulta, Timofeevia phosphoritica and Timofeevia aff. estonica are numerically important taxa in all three assemblages. Actinotodissus achrasii and Trunculumarium revinium are also numerically important in L1, Cristallinium cambriense in L2 and L3, and Stelliferidium cortinulamorphum in L1 and L3. Sample L1 yielded the most taxonomically diverse assemblage, distinguished from the others importantly by the presence of $T$. revinium. The L3 assemblage, in addition to the absence of T. revinium, lacks $A$. achrasii and Impluviculus sp. 1 found in the other assemblages. The stratigraphically important taxa Cristallinium randomense, Ninadiacrodium caudatum (questionable in L2), Leiofusa stoumonensis and Ninadiacrodium dumontii are present in all three assemblages. Scalenadiacrodium comleyense is a significant component of the L2 and L3 assemblages. Leiofusa stoumonensis, Ninadiacrodium dumontii and Vulcanisphaera africana are numerically more important components of the L2 assemblage, whilst Stelliferidium cortinulamorphum has its greatest numerical expression in assemblage L3.

\section{COMPARISON WITH OTHER AREAS}

The Comley area assemblages are compared here with those of known age elsewhere, as well as those less well age-controlled, but that can be related to published acritarch zonations. Eastern Newfoundland provides the most intensively studied and comprehensively trilobite dated area for correlation (Martin \& Dean, 


\begin{tabular}{|c|c|c|c|c|c|c|}
\hline & \multicolumn{3}{|c|}{ Acritarch species counts } & \multicolumn{3}{|c|}{ Relative abundance (\%) } \\
\hline Cristallinium cambriense & 22 & 55 & $\mathrm{P}$ & 3.7 & 11.6 & $\mathrm{P}$ \\
\hline Cristallinium randomense & 3 & 2 & $\mathrm{P}$ & 0.5 & 0.4 & $\mathrm{P}$ \\
\hline Cymatiogalea aff. aspergillum & 6 & 1 & 2 & 1.0 & 0.2 & 0.6 \\
\hline Cymatiogalea virgulta & 292 & 170 & 165 & 48.7 & 35.7 & 48.0 \\
\hline Leiosphaeridia spp. & 6 & 26 & 6 & 1.0 & 5.5 & 1.7 \\
\hline Ninadiacrodium caudatum & $\mathrm{P}$ & $\mathrm{P} ?$ & $\mathrm{P}$ & $\mathrm{P}$ & $\mathrm{P} ?$ & $\mathrm{P}$ \\
\hline Ninadiacrodium aff. caudatum & 1 & $\mathrm{P}$ & 1 & 0.2 & $\mathrm{P}$ & 0.3 \\
\hline Ninadiacrodium dumontii & $\mathrm{P}$ & 18 & $\mathrm{P}$ & $\mathrm{P}$ & 3.8 & $\mathrm{P}$ \\
\hline Polygonium spp. & $\mathrm{P}$ & 1 & 1 & $\mathrm{P}$ & 0.2 & 0.3 \\
\hline Timofeevia phosphoritica & 129 & 100 & 51 & 21.5 & 21.0 & 14.8 \\
\hline Vulcanisphaera africana & 6 & 14 & 6 & 1.0 & 2.9 & 1.7 \\
\hline Vulcanisphaera turbata & 6 & 5 & $\mathrm{P}$ & 1.0 & 1.1 & $\mathrm{P}$ \\
\hline Actinotodissus achrasii & & $\mathrm{P} ?$ & 25 & & $\mathrm{P}$ ? & 7.3 \\
\hline Impluviculus sp. 1 & & 1 & $\mathrm{P}$ & & 0.2 & $\mathrm{P}$ \\
\hline Gyalorhethium? sp. 1 & & & 1 & & & 0.3 \\
\hline Trunculumarium revinium & & & 34 & & & 9.9 \\
\hline Total & 600 & 476 & 344 & & & \\
\hline
\end{tabular}

Table 1. Acritarch occurrence and relative abundances in the three assemblages from the Comley area.

p, present out of count; ?, questionable identification

1981, 1988; Parsons \& Anderson, 2000). Trilobite-controlled dating of acritarch assemblages is also available from the Nuneaton area of England (Potter reported in Bridge et al., 1998, and unpublished data). Both these areas share with Comley a palaeogeographical location on the Avalonian microcontinent on the northern fringes of Gondwana (Fig. 4). Similar but less well age-controlled assemblages are reported from the Ardennes area (mainly Belgium) and the East European Platform (primarily Estonia).

The Comley assemblages are closely comparable to those reported by Martin (in Martin \& Dean, 1981, 1988) from the Manuels River and Random Island areas of eastern Newfoundland. Although Parsons \& Anderson (2000) examined only one additional sample from the interval comparable with Comley, new trilobite data are reported and some of Martin \& Dean's (1981, 1988) samples are repositioned in relation to the trilobite stratigraphy. They also provide a thorough critique of Martin \& Dean's (1981, 1988) acritarch zonation and provide a zonation of their own. The implications for the age control of the Comley assemblages of the differing interpretations of the trilobite control in eastern Newfoundland suggested by Martin \& Dean and by Parsons \& Anderson are considered here. The relationship of the two microfloral schemes to the trilobite zones, including Parsons \& Anderson's interpretation of the Martin \& Dean scheme, is shown in Figure 5.

Assemblage L1 is directly comparable to microflora RA4 of Parsons \& Anderson (2000) and the lower part of microflora A4 of Martin in Martin \& Dean (1988), principally defined by the presence in quantity of Trunculumarium revinium. In addition to common $T$. revinium, the presence of Actinotodissus achrasii (present in A4 assemblages), Ninadiacrodium caudatum, Leiofusa stoumonensis and Ninadiacrodium dumontii, in particular, further support an RA4 equivalence. Whilst these taxa are not restricted to the RA4 assemblage, their presence in the absence of Actinotodissus cf. A. ubui (Martin, 1969) Martin in Martin \& Dean, 1988, Orthosphaeridium? extensum Parsons \& Anderson, 2000 and Ladogella rommelaerei (Martin in Martin \& Dean, 1981) Di Milia et al., 1989, first appearing in the succeeding RA5 microflora, strongly supports an RA4 assignment. Parsons \& Anderson (2000) equate the RA4 microflora with part of the A4 microflora of Martin \& Dean (1981, 1988), but exclude three of the assemblages (those without $T$. revinium in quantity), reassigning them to their younger RA5 unit.

Assemblages L2 and L3 comprise, amongst other taxa, Cristallinium randomense, Ninadiacrodium dumontii, and a form similar to Cymatiogalea aspergillum which, by their first appearance, define the base of Martin \& Dean's (1981, 1988) A3 microflora. Vulcanisphaera africana and Impluviculus sp. A (Impluviculus sp. 1 of the Comley assemblages) also make their first appearances in the A3 microflora. Cymatiogalea virgutta, abundant in the Comley assemblages, is present. The additional presence, although very infrequent, in the L2 and L3 assemblages of $N$. caudatum (questionable in L2) and D. obsonum further restricts correlation to a microflora no older than A3b of Martin $\&$ Dean (1988), which has a base defined by the first appearance of such diacrodian taxa. The presence of Ninadiacrodium aff. caudatum and Scalenadiacrodium comleyense sp. nov., both diacrodian taxa, and Polygonium spp., some of which appear to fall 
within the variability of Stellechinatum uncinatum (Downie, 1958) Molyneux, 1987 as reported from eastern Newfoundland and with a base in A3b, further supports an A3b (or younger) assignment.

The succeeding A4 microflora is distinguished from A3b almost entirely on the presence of Trunculumarium revinium. However, most taxa present in the A3b microflora range through A4 into A5 so that there are few criteria for distinguishing an A3b from a (lower part) A5 microflora. The Comley assemblages L2 and L3 are from isolated exposures in a structurally complex setting and their stratigraphical relationship to the A4 equivalent (L1) is not known. Furthermore, the nature of the microflora immediately succeeding that of A4 in eastern Newfoundland is unknown. Both Martin \& Dean (1981) and Parsons \& Anderson (2000) recognized a fault separating the shales assignable to the Parabolina spinulosa Zone from younger strata. The microflora (lower part A4 with common Trunculumarium revinium) below the fault occurs together with Parabolina spinulosa (Martin \& Dean, 1981), the index fossil for the upper subzone of the P. spinulosa Zone. The Parsons \& Anderson (2000) interpretation requires the faulting out of the Leptoplastus Zone, resulting in the succeeding Protopeltura praecursor Zone directly overlying the $P$. spinulosa Zone. If a sequence assignable to the Leptoplastus trilobite Zone succeeds the P. spinulosa Zone, as suggested by Martin \& Dean (1981, 1988), the faulting may have only minor consequence and the nature of an immediately post- $P$. spinulosa Zone microflora can be characterized to a limited extent. The first appearance of Actinotodissus cf. A. ubui in the Leptoplastus Zone would assist in distinguishing the $P$. spinulosa Zone from younger assemblages and support an A3b assignment for the L1 and L2 acritarch microflora. Leiofusa stoumonensis, common in the L2 and present in the L3 microflora, is only present (rare) in one Leptoplastus Zone assemblage (Martin \& Dean, 1988) and was not recorded in the post-RA4 samples analysed by Parsons \& Anderson (2000). The two RA5 index taxa Orthosphaeridium? extensum and Ladogella rommelaerei are absent from the Comley assemblages. Timofeevia estonica Volkova, 1990 does not range above RA4, according to Parsons \& Anderson (2000), thus the presence of (common) Timofeevia aff. estonica in L2 and L3 may also point towards an $\mathrm{A} 3 \mathrm{~b}$ rather than an RA5 assignment. The absence of $T$. revinium from L2 and L3 may be of little significance because, although missing from $\mathrm{A} 3 \mathrm{~b}$ assemblages, it is only extremely rare in those of RA5. Some discrepancies are noted. Cymatiogalea virgulta is abundant in the L2 and L3 assemblages but in eastern Newfoundland it is not present in quantity prior to the Leptoplastus Zone (Martin \& Dean 1988) or Peltura minor Zone (Parsons \& Anderson 2000). Timofeevia phosphoritica, abundant in all three Comley assemblages, is relatively rare in the A3, A4 and RA4 microfloras of eastern Newfoundland.

Martin \& Dean (1988) assigned microflora A3b and the upper part of A3a to the Parabolina spinulosa Zone. A microfloral assemblage (GSC 87793) referred to ?A4 in Martin \& Dean (1981), apparently reassigned to A3b in Martin \& Dean (1988, figure 9 ; p. 33) was found in association with $P$. spinulosa, indicative of the upper subzone of the $P$. spinulosa Zone. The remaining A3b and the upper part A3a assemblages were assigned to the P. spinulosa Zone on the basis of their association with Orusia lenticularis (Wahlenberg, 1821), a brachiopod generally considered a reliable indicator for the trilobite zone (see Martin \& Dean, 1988, p. 14). Martin \& Dean found no evidence for the lower
Parabolina brevispina Subzone. Parsons \& Anderson (2000) reported the presence of $P$. brevispina, indicative of the $P$. brevispina Subzone, and assigned A3a to the subzone with a possible extension into the $P$. spinulosa Subzone. They assigned A3b in its entirety to the $P$. spinulosa Subzone but with uncertainty concerning the position of the microflora's base (Parsons \& Anderson 2000, text-fig. 2). Unfortunately, the trilobite evidence of Parsons \& Anderson (2000) is not supported by illustrations.

Considering this evidence, the Comley microfloras L2 and L3 can be referred to the A3b microfloral subdivision of Martin \& Dean (1988), equivalent to the lower part of the $P$. spinulosa Subzone of the $P$. spinulosa Zone. The L1 microflora can be referred to the lower part of the A4 subdivision of Martin \& Dean (1988) and RA4 subdivision of Parsons \& Anderson (2000). The lower part of A4 is equivalent to the upper part of the P. spinulosa Subzone. The upper boundary of the lithological unit assigned to the lower part A4 (and RA4) microfloral subdivisions is faulted with section missing; therefore, it is theoretically possible that the microflora could extend into the Leptoplastus Zone in Martin \& Dean's interpretation or to the Protopeltura praecursor Zone in Parsons \& Anderson's interpretation. There are no reliable macrofaunally controlled microfloras described from the Leptoplastus Zone elsewhere for comparison. Parsons \& Anderson (2000) maintained that attribution of an impoverished microfloral assemblage from Norway to the Leptoplastus Zone (Welsch, 1986) is insufficiently supported by macrofaunal evidence.

One of the authors (Potter, unpublished data) has studied an acritarch assemblage from the British Geological Survey borehole Merevale No. 1 from an interval dated on trilobite evidence as belonging to the $P$. brevispina Subzone of the Parabolina spinulosa Zone (see Taylor \& Rushton, 1972 for full details of the trilobite zonal assignment). The results from the sample at 350'2" in the Monks Park Shale Formation, briefly mentioned by Bridge et al. (1998), are outlined here. The assemblage includes, amongst other taxa, Trunculumarium revinium (in quantity), Actinotodissus sp., Cristallinium cambriense, Cymatiogalea sp., Ninadiacrodium caudatum, Impluviculus sp. 1, Leiofusa stoumonensis, Ninadiacrodium dumontii and Timofeevia aff. estonica. This assemblage, though poorly preserved, closely resembles the L1 assemblage from Comley and the RA4 (Parsons \& Anderson, 2000) and lower part A4 (Martin \& Dean, 1988) microfloras from eastern Newfoundland. The Merevale No. 1 acritarch assemblage is derived from a horizon near the top of an interval assigned by Taylor \& Rushton (1972) to the P. brevispina Subzone and indicates that the lower boundary of an RA4 microflora can occur within the $P$. brevispina trilobite Subzone in England, earlier than is apparently the case in eastern Newfoundland.

Published descriptions of acritarch assemblages from successions with reliable macrofaunal control to indicate a Parabolina spinulosa Zone are not currently available from other localities. However, the distinctive nature of the Comley assemblages permits comparison with others, principally from Belgium, and the East European Platform of western Russia and the Baltic states.

The Cambrian palynostratigraphy of Belgium has been extensively reported and a zonation developed by Vanguestaine (1974, 1978, 1986) Ribecai \& Vanguestaine (1993) and Ribbert et al., (2001). The assemblage of Zone 5 from the Revin Group (Rn2b) of the Stavelot Massif (Vanguestaine, 1973, 1974; Ribecai \& Vanguestaine, 1993) closely resembles the L1 assemblage from 
Comley. The presence of $T$. revinium without species of the genus Ladogella and the presence of $N$. caudatum and $N$. dumontii support the comparison. The preceding Zone 4 (Vanguestaine, 1974, subdivided into $4 \mathrm{a}$ and $4 \mathrm{~b}$ in Vanguestaine, 1978) encompasses assemblages that pre-date the first appearances of $N$. caudatum and $N$. dumontii and cannot be compared with the L2 and L3 assemblages of Comley. However, Ribbert et al. (2001) mention a third subdivision, ' $4 \mathrm{c}$ ' of Zone 4, the microflora of which (from the Stavelot-Venn Anticline) shows some similarities with assemblages L2 and L3, containing N. dumontii and Leiofusa stoumonensis in the absence of $T$. revinium. However, the presence of Ninadiacrodium caudatum and Dasydiacrodium obsonum in the Comley samples suggests a slightly younger age for L2 and L3. The three Comley assemblages would be encompassed by the Trunculumarium revinium-Veryhachium dumontii Superzone V of the international zonation of Vanguestaine \& Van Looy (1983), a scheme which combined the Belgian zones with others available at that time.

Similar assemblages to those at Comley have been reported from the East European Platform area, mainly from Estonia, Ukraine and western Russia. Expanding upon the data in Volkova (1990), Volkova \& Kir'yanov (1995) summarize a regional scheme for the East European Platform. Comley assemblages L2 and L3 can be compared with the upper subdivision (VK2b) of the 'Vorchin regional horizon' VK2 (Volkova, 1990). The base coincides with the first appearances of the taxa Leiofusa stoumonensis, Ninadiacrodium dumontii and Timofeevia estonica, with the species Ninadiacrodium caudatum and Stellechinatum uncinatum (Downie, 1958) Molyneux, 1987 appearing within the zone and defining the base of the upper VK2b subdivision (Volkova \& Kir'yanov, 1995). Whilst S. uncinatum does not occur in the Comley assemblages (some specimens of Polygonium spp. with pronounced sculpture begin to resemble this form), an assemblage above base $N$. caudatum and below base $T$. revinium would satisfactorily describe L2 and L3 which, therefore, can be compared with VK2b assemblages.

Two assemblages described by Paalits (1992b, 1995) from western Russia and North Estonia resemble L2 and L3 of Comley. An assemblage from the Panikovitshi core of the Petseri Formation in the Pskov Region of Russia (Paalits, 1992b), whilst not containing $N$. caudatum or D. obsonum, does include a probable dasydiacrodian ?Dasydiacrodium setuensis Paalits, 1992b, L. stoumonensis and Veryhachium incus Paalits, 1992b, a junior synonym of $N$. dumontii. Paalits (1992b) argues that this assemblage may pre-date the inception of the genus Impluviculus (Loeblich \& Tappan, 1969) Martin, 1977, a taxon present in the L2 assemblage of Comley. The assemblage may be of similar age to or slightly older than assemblages L2 and L3. The second assemblage including Cristallinium randomense, Stelliferidium cortinulamorphum, Ninadiacrodium dumontii and Leiofusa stoumonensis, reported as assemblage A1 from the upper part of the Ülgase Formation of the Tõnismägi outcrop, North Estonia (Paalits, 1995), also lacks $N$. caudatum and D. obsonum. However, the assemblage includes ?Leiofusa sp., which Paalits (1995) compares with 'Leiofusa scalenabullata Potter, 1974' (nomen nudum, herein published as Scalenadiacrodium comleyense gen. et sp. nov.) and which is characteristic of L2 and L3. Paalits (1995) notes, as a personal communication from Parsons, the occurrence of a similar species in Newfoundland from the 'lower and middle parts of the
Parabolina spinulosa Zone'. In overall characteristics, the A1 assemblage resembles L2 and L3 from Comley although there is a greater variety of the galeate taxa (Cymatiogalea and Stelliferidium).

Volkova (1990) presented an assemblage from the North Estonian Mardu-9 borehole (137.4-146 m), including N. caudatum, N. dumontii, L. stoumonensis and common T. revinium, which she assigned to Zone VK3. The topmost sample includes Lusatia dendroidea Burmann, 1970, a form typical of younger Cambrian assemblages. The L1 assemblage corresponds well with the underlying microflora (138.4-146 m) and could thus be considered equivalent to the lower part of Zone VK3 in the Mardu-9 sequence. Parsons \& Anderson (2000, p. 10) also note the anomalous occurrence of $L$. dendroidea and suggest that, as the preceding samples are from the Tsitre Formation and are separated by a considerable stratigraphical break from the overlying Mardu Member (sample with $L$. dendroidea), the latter sample should be reassigned to the younger VK5 assemblage of Volkova (1990). Parsons \& Anderson (2000) explain the anomalous occurrence of common $T$. revinium together with $L$. dendroidea as a result of reworking. Parsons \& Anderson (2000) also invoke reworking to explain the presence of typical VK3 taxa, including Leiofusa stoumonensis and Ninadiacrodium caudatum, in the succeeding VK4A subdivision of the Volkova (1990) zonation for the East European Platform. An assemblage described by Paalits (1992a) from the Tsitre Formation of borehole core M-72 (112.8-119.6 m), North Estonia, is very closely comparable to Comley assemblage L1. The same core interval is adopted as stratotype for the 'Tsitre regional horizon' by Volkova \& Kir'yanov (1995) and assigned to their VK3 acritarch complex. As in the Comley L1 assemblage, Trunculumarium revinium, Timofeevia estonica (comparable with $T$. aff. estonica of Comley) and a form Cymatiogalea aff. virgulta, illustrated but not described, possibly similar to $C$. virgulta, are common and D. obsonum, L. stoumonensis, N. caudatum and $N$. dumontii present. Volkova \& Kir'yanov (1995) state that deposits yielding a VK3 assemblage transgressively overlie those yielding a VK2 assemblage in North Estonia. This would support the assignment of a younger age to the L1 assemblage (similar to VK3) than to the L2 and L3 assemblages (similar to VK2b).

Ghavidel-syooki \& Vecoli (2008) report acritarch assemblages including Trunculumarium revinium from the High Zagros Mountains of southern Iran. The majority of the species comprising acritarch assemblage zone IVa are encountered in the Comley L1 assemblage but the additional presence of abundant Lusatia dendroidea Burmann, 1970, emend. Albani et al., 2007, would indicate a slightly younger age for the assemblage. Assuming that the presence of $L$. dendroidea is not the result of palaeogeographical or palaeoenvironmental influences on an assemblage ageequivalent to the RA4 microflora (Parsons \& Anderson, 2000) of eastern Newfoundland, the Iranian assemblage may represent an unsampled or missing interval in the eastern Newfoundland succession preceding the first occurrence of Orthosphaeridium? extensum and Ladogella rommelaerei in both areas.

The microflora of the Maentwrog and Ffestiniog Flags Formation of the St Tudwal's Peninsula and St Tudwal's Island East in North Wales is described by Martin in Young et al. (1994) and reviewed by Martin in Young et al. (2002). The Maentwrog Formation is tentatively assigned, on trilobite evidence, to the Olenus Zone. The microfloras, which include C. aspergillum, 
C. virgulta, L. stoumonensis, T. phosphoritica and $V$. turbata, are compared with the upper part of the microfloras A2 and A3a of eastern Newfoundland (Olenus trilobite Zone/lower part of Parabolina spinulosa Zone). Diacrodian taxa are absent, although $N$. dumontii is present elsewhere in the North Wales Ffestiniog Flags Formation. For this reason, the assemblage is here considered to pre-date those of the Comley area.

Although the assemblages are not necessarily closely comparable, some distinctive taxa in the Comley assemblages are reported from North Africa (Vecoli, 1996, 1999), northern Norway (Welsch, 1986), Poland (Szczepanik, 2001; Żylińska et al., 2006), Ireland (Vanguestaine \& Brück, 2008) and Arctic Russia (Raevskaya \& Golubkova, 2006).

\section{CONCLUSIONS}

The Furongian Shoot Rough Road Shales of the Comley area yield numerically abundant, taxonomically diverse and generally well-preserved assemblages of acritarchs. The macrofossil zone assignment of the Shales to the Furongian Parabolina spinulosa trilobite Zone by Cobbold (summary in Cobbold, 1927) can now be further restricted to the Parabolina spinulosa Subzone.

Two distinct microfloras are comparable with Parabolina spinulosa Zone assemblages from Newfoundland and Nuneaton, England. The Comley L2 and L3 assemblages resemble the Newfoundland Microflora 3b of Martin \& Dean (1988) assigned to the Parabolina spinulosa Subzone (lower part). In the absence of any published definitive Leptoplastus Zone microfloras for comparison with the Comley L2 and L3 assemblages, a Leptoplastus Zone age for L2 and/or L3 cannot be entirely ruled out. The L1 assemblage resembles Microflora A4 (lower part) of Martin \& Dean (1988) and Microflora RA4 of Parsons \& Anderson (2000), assigned to the upper part of the Parabolina spinulosa Subzone. The L1 assemblage also resembles a microflora from the Parabolina brevispina Subzone of the Parabolina spinulosa Zone recovered from BGS borehole Merevale No. 1, Nuneaton, but differs from the assemblage that characterizes the Subzone in Newfoundland. The resolution of this discrepancy must await the acquisition of additional data to determine whether palaeoenvironmental, palaeogeographical or sampling constraints are responsible.

Similar assemblages have also been reported primarily from the Ardennes and the East European Platform. Assemblage L1 is similar to that of Zone 5 of Ribecai \& Vanguestaine (1993) from the Stavelot Massif, Ardennes, Belgium. The L2 and L3 microflora corresponds with the acritarch complex VK2b of Volkova \& Kir'yanov (1995) and the L1 assemblage is comparable with the lower part of acritarch complex and VK3 of Volkova (1990) from the East European Platform.

Acritarchs are shown to have considerable biostratigraphical potential for high-resolution biostratigraphy in the classic Comley area and should be used in any further investigation of the area as new exposures are identified. This contribution extends our knowledge of the microfloral characterization of the Parabolina spinulosa trilobite Zone.

\section{ACKNOWLEGEMENTS}

The authors wish to thank John E. Williams (London) for unfettered access to the John Williams Index of Palaeopalynology at the Natural History Museum, Adrian W. A. Rushton (London) for expert advice on the significance of the trilobite data relevant to this investigation, Martin Allbutt (Church Stretton) for kindly directing us across the eastern flank of Caer Caradoc to location L3. Thanks also to Andrew Seabury of Comley Farm and Steven Pennington of Wilstone Farm for permission to collect samples from their land. Brian Pedder gratefully acknowledges a NERC MSc grant. J.E.A. Marshall (Southampton) and M. Moczydłowska (Uppsala) reviewed the manuscript and are thanked for helpful comments.

\section{Manuscript received 12 March 2010 \\ Manuscript accepted 26 September 2010}

Scientific editing by John Marshall

\section{REFERENCES}

Albani, R., Di Milia, A., Minzoni, N. \& Tongiorgi, M. 1985. Nuovi dati palinologici e considerazioni geologiche sull'eta delle Arenarie di Solanas (Cambro-Ordoviciano-Sardegna Centrale). Atti della Società Toscana di Scienze Naturali, Memorie, Serie A, 92: 1-33.

Albani, R., Massa, D. \& Tongiorgi, M. 1991. Palynostratigraphy (acritarchs) of some Cambrian beds from the Rhadames (Ghadamis) Basin (western Libya-southern Tunisia). Bollettino della Società Paleontologica Italiana, 30: 255-280.

Albani, R., Bagnoli, G., Bernárdez, E., Gutíerrez-Marco, J.C. \& Ribecai, C. 2006. Late Cambrian acritarchs from the 'Túnel Ordovícico del Fabar', Cantabrian Zone, N Spain. Review of Palaeobotany and Palynology, 139: 41-52.

Albani, R., Bagnoli, G., Ribecai, C. \& Raevskaya, E. 2007. Late Cambrian acritarch Lusatia: taxonomy, palaeogeography, and biostratigraphic implications. Acta Palaeontologica Polonica, 52: 809-818.

Aráoz, L. \& Vergel, M.M. 2006. Palinologia de la transición CambroOrdovícica en Quebrada de Moya, Cordillera Oriental, Argentina. Revista Brasileira de Paleontologia, 9: 1-8.

Bagnoli, G., Stouge, S. \& Tongiorgi, M. 1988. Acritarchs and conodonts from the Cambro-Ordovician Furuhäll (Köpingsklint) section (Öland, Sweden). Rivista Italiana di Paleontologia e Stratigrafia, 94: 163-248.

Bridge, D.McC., Carney, J.N., Lawley, R.S. \& Rushton, A.W.A. 1998. The geology of the country around Coventry and Nuneaton. Memoir of the Geological Survey of Great Britain, Sheet 169 (England and Wales). HMSO, London, 185pp.

Burmann, G. 1968. Diacrodien aus dem unteren Ordovizium. Paläontologische Abhandlungen Abteilung B Paläobotanik II, 635-793.

Burmann, G. 1970. Weitere organische Mikrofossilien aus dem unteren Ordovizium. Paläontologische Abhandlungen Abteilung B, 3: 289-332.

Cobbold, E.S. 1909. On some excavations in the Cambrian rocks of Comley, Shropshire. Report of the British Association for the Advancement of Science, for 1908: 231-242.

Cobbold, E.S. 1910. On some further excavations among the Cambrian rocks of Comley, Shropshire, 1908. Report of the British Association for the Advancement of Science, for 1909: 181-185.

Cobbold, E.S. 1912. Fourth report on excavations among the Cambrian rocks of Comley, Shropshire. Report of the British Association for the Advancement of Science, for 1911: 111-115.

Cobbold, E.S. 1916. Sixth report on excavations among the Cambrian rocks of Comley, Shropshire (1912, 1913, 1914). Report of the British Association for the Advancement of Science, for 1915: 117-123.

Cobbold, E.S. 1921. The Cambrian horizons of Comley (Shropshire) and their brachiopoda, pteropoda, gasteropoda etc. Quarterly Journal of the Geological Society of London, 76: 325-386.

Cobbold, E.S. 1927. The stratigraphy and geological structure of the Cambrian area of Comley (Shropshire). Quarterly Journal of the Geological Society of London, 83: 551-573.

Cobbold, E.S. 1933. Notes on Comley Quarry, near Church Stretton, Shropshire. Report of the British Association for the Advancement of Science, for 1927: 473-476. 
Cocks, L.R.M. \& Torsvik, T.H. 2002. Earth geography from 500 to 400 million years ago: a faunal and palaeomagnetic review. Journal of the Geological Society, London, 159: 631-644.

Cocks, L.R.M., Fortey, R.A. \& Rushton, A.W.A. 2010. Correlation for the Lower Palaeozoic. Geological Magazine, 147: 171-180.

Combaz, A., Lange, F.W. \& Pansart, J. 1967. Les "Leiofusidae" Eisenack, 1938. Review of Palaeobotany and Palynology, 1: 291-307.

Cowie, J.W., Rushton, A.W.A. \& Stubblefield, C.J. 1972. A correlation of Cambrian rocks in the British Isles. Geological Society, Special Report, 2: $1-42$.

Cramer, F.H. \& Diez de Cramer, M. del C.R. 1972. Acritarchs from the upper Middle Cambrian Oville Formation of León, northwestern Spain. Revista Española de Micropaleontología, número extraordinario, 30 : 39-50.

Dean, W.T. \& Martin, F. 1978. Lower Ordovician acritarchs and trilobites from Bell Island, eastern Newfoundland. Bulletin of the Geological Survey of Canada, 284: 1-27.

Deflandre, G. \& Deflandre-Rigaud, M. 1962. Nomenclature et systématique des Hystrichosphères (sens. lat.). Observations et rectifications. Revue de Micropaléontologie, Paris, 4: 190-196.

Deunff, J. 1954. Veryhachium, genre nouveau d'Hystrichosphères du Primaire. Compte rendu sommaire des séances da la Société géologique de France, 13: 305-306.

Deunff, J. 1961. Un microplancton à Hystrichosphères dans le Trémadoc du Sahara. Revue de Micropaléontologie, 4: 37-52.

Deunff, J. 1968. Sur une forme nouvelle d'Acritarche possédant une ouverture polaire (Veryhachium miloni n.sp.) et sur la présence d'une colonie de Veryhachium dans le Trémadocien marocain. Comptes rendus des séances de l'Académie des sciences, 267: 46-49.

Deunff, J., Gorka, H. \& Rauscher, R. 1974. Observations nouvelles et précisions sur les Acritarches à large ouverture polaire du Paléozoïque inférieur. Géobios, 7: 5-18.

Di Milia, A. 1991. Upper Cambrian acritarchs from the Solanas Sandstone Formation, Central Sardinia, Italy. Bollettino della Società Paleontologica Italiana, 30: 127-152.

Di Milia, A. \& Tongiorgi, M. 1993. Tremadocian acritarch assemblages from the Solanas Sandstone Formation (Nappe Zone of central Sardinia). Memorie della Società Geologica Italiana, 49: 193-204.

Di Milia, A., Ribecai, C. \& Tongiorgi, M. 1989. Late Cambrian acritarchs from the Peltura scarabaeoides Trilobite Zone at Degerhamn (Öland, Sweden). Palaeontographia Italica, 76: 1-56.

Downie, C. 1958. An assemblage of microplankton from the Shineton Shales (Tremadocian). Proceedings of the Yorkshire Geological Society, 31: 331-349.

Downie, C. \& Sarjeant, W.A.S. 1963. On the interpretation and status of some hystrichosphere genera. Palaeontology, 6: 83-96.

Eichwald, C.E. 1840. Ueber das silurische Schichtensystem in Esthland. Zeitschrift für Natur- und Heilkunde der medizinischen Akademie zu St. Petersburg, Hefte 1-2, 210pp.

Eisenack, A. 1934. Neue Mikrofossilien des baltischen Silurs. III. und Neue Mikrofossilen des böhmischen Silurs. I. Paläontologische Zeitschrift, 16: 52-76.

Eisenack, A. 1938. Hystrichosphaerideen und verwandte Formen im baltischen Silur. Zeitschrift für Geschiebeforschung und Flachlandgeologie, 14: $1-30$

Eisenack, A. 1958. Tasmanites Newton 1875 und Leiosphaeridia n.g. als Gattungen der Hystrichosphaeridea. Palaeontographica, Abteilung A, 110: $1-19$.

Evitt, W.R. 1963. A discussion and proposals concerning fossil dinoflagellates, hystrichospheres, and acritarchs. I. Proceedings of the National Academy of Sciences of the United States of America, 49: 158-164.

Fensome, R.A., Williams, G.L., Barss, M.S., Freeman, J.M. \& Hill, J.M. 1990. Acritarchs and fossil prasinophytes: an index to genera, species and infraspecific taxa. American Association of Stratigraphic Palynologists, Contributions Series, 25, 771pp.
Ghavidel-syooki, M. 2006. Palynostratigraphy and palaeogeography of the Cambro-Ordovician strata in southwest of Shahrud City (Kuhe-Kharbash, near Deh-Molla), Central Alborz Range, northern Iran. Review of Palaeobotany and Palynology, 139: 81-95.

Ghavidel-syooki, M. \& Vecoli, M. 2008. Palynostratigraphy of Middle Cambrian to lowermost Ordovician stratal sequences in the High Zagros Mountains, southern Iran: Regional stratigraphic implications, and palaeobiogeographic significance. Review of Palaeobotany and Palynology, 150: 97-114.

Greig, D.C., Wright, J.E., Hains, B.A. \& Mitchell, G.H. 1968. Geology of the Country around Church Stretton, Craven Arms, Wenlock Edge and Brown Clee. Memoir of the Geological Survey of Great Britain, sheet 116 (England and Wales), HMSO, London, 379pp.

Henningsmoen, G. 1957. The trilobite family Olenidae. Skrifter utgitt av Det Norske Videnskaps-Akademi i Oslo. 1. Matematisk-Naturvidenskapelig Klasse for 1957, 1: 1-303.

Hinz, I. 1987. The Lower Cambrian microfauna of Comley and Rushton, Shropshire/England. Palaeontographica Abteilung A, 198: 41-100.

Jacobson, S.R. \& Achab, A. 1985. Acritarch biostratigraphy of the Dicellograptus complanatus graptolite zone from the Vaureal Formation (Ashgillian), Anticosti Island, Quebec, Canada. Palynology, 9: 165-198.

Lapworth, C. 1888. On the discovery of the Olenellus fauna in the Lower Cambrian rocks of Britain. Nature, 39: 212-213.

Linnarsson, J.G.O. 1876. Brachiopoda of the Paradoxides beds of Sweden. Bihang till Kongliga Svenska Vetenskaps-Akademiens Handlingar, 3: $1-34$.

Loeblich, A.R. Jr. 1970. Morphology, ultrastructure and distribution of Paleozoic acritarchs. Proceedings of the North American Paleontological Convention, Chicago, 1969, part G, 2: 705-788.

Loeblich, A.R. Jr. \& Tappan, H. 1969. Acritarch excystment and surface ultrastructure with descriptions of some Ordovician taxa. Revista española de micropaleontologia, 1: 45-57.

Loeblich, A.R. Jr. \& Tappan, H. 1976. Some new and revised organicwalled phytoplankton microfossil genera. Journal of Paleontology, 50: 301-308.

Loeblich, A.R. Jr. \& Tappan, H. 1978. Some Middle and Late Ordovician microphytoplankton from central North America. Journal of Paleontology, 52: 1233-1287.

Martin, F. 1969. Les Acritarches de l'Ordovicien et du Silurien belges. Détermination et valeur stratigraphique. Institut royal des sciences naturelles de Belgique, Mémoire, 160: 1-175 (cover date 1968, issue date 1969).

Martin, F. 1973. Les Acritarches de l'Ordovicien inférieur de la Montagne Noire (Hérault, France). Bulletin, Institut Royal des Sciences Naturelles de Belgique, 48: 1-61 (cover date 1972, issue date 1973).

Martin, F. 1977. Acritarches du Cambro-Ordovicien du Massif du Brabant, Belgique. Bulletin de l'Institut Royal des Sciences Naturelles de Belgique, Sciences de la Terre, 51: 1-33 (cover date 1975, issue date 1977).

Martin, F. 1993. Acritarchs: a review. Biological Reviews, 68: 475-538.

Martin, F. \& Dean, W.T. 1981. Middle and Upper Cambrian and Lower Ordovician acritarchs from Random Island, eastern Newfoundland. Geological Survey of Canada, Bulletin, 343: 43pp.

Martin, F. \& Dean, W.T. 1988. Middle and Upper Cambrian acritarch and trilobite zonation at Manuels River and Random Island, eastern Newfoundland. Geological Survey of Canada, Bulletin, 381: 91pp.

Mens, K., Paalits, I. \& Puura, I. 1997. Upper Cambrian acritarchs from the basal conglomerate of the Kallavere Formation on the Pakri Peninsula, NW Estonia. In Fatka, O. \& Servais, T. (Eds), Acritarcha in Praha 1996. Acta Universitatis Carolinae Geologica, 40: 531-543.

Miller, M.A. \& Al-Ruwaili, M.H. 2007. Preliminary palynological investigation of Saudi Arabian Upper Ordovician glacial sediments. Revue de Micropaléontologie, 50: 17-26.

Moczydłowska, M. 1998. Cambrian acritarchs from Upper Silesia, Poland - biochronology and tectonic implications. Fossils and Strata, 46: $1-121$. 
Moczydłowska, M. \& Stockfors, M. 2004. Acritarchs from the CambrianOrdovician boundary interval on Kolguev Island, Arctic Russia. Palynology, 28: 15-73.

Molyneux, S.G. 1987. II. Appendix. Acritarchs and chitinozoa from the Arenig Series of south-west Wales. In: The Arenig Series in south Wales: stratigraphy and palaeontology. Bulletin of the British Museum (Natural History), Geology, 41: 309-364.

Paalits, I. 1992a. Upper Cambrian acritarchs from boring core M-72 of North Estonia. Proceedings of the Estonian Academy of Sciences, Geology, 41: 29-37.

Paalits, I. 1992b. Upper Cambrian acritarchs from the Petseri Formation (East European Platform). Acta et Commentationes Universitatis Tartuensis, 956: 44-55.

Paalits, I. 1995. Acritarchs from the Cambrian-Ordovician boundary beds at Tõnismägi, Tallinn, North Estonia. Proceedings of the Estonian Academy of Sciences, Geology, 44: 87-96.

Paalits, I. \& Heuse, T. 2000. Taxonomic review of the acritarch genera Acanthodiacrodium Timofeev, 1958 and Diornatosphaera Downie, 1958. Bollettino della Società Paleontologica Italiana, 39: 311-317.

Palacios, T., Jensen, S., Barr, S.M. \& White, C.E. 2009. Acritarchs from the MacLean Brook Formation, southeastern Cape Breton Island, Nova Scotia, Canada: New data on Middle Cambrian-Lower Furongian acritarch zonation. Palaeogeography, Palaeoclimatology, Palaeoecology, 273: 123-141.

Parsons, M.G. \& Anderson, M.M. 2000. Acritarch microfloral succession from the Late Cambrian and Ordovician (Early Tremadoc) of Random Island, eastern Newfoundland, and its comparison to coeval microflora, particularly to those of the East European Platform. American Association of Stratigraphic Palynologists Foundation Contribution Series, 38: 123pp.

Pittau, P. 1985. Tremadocian (Early Ordovician) acritarchs of the Arburese Unit, southwest Sardinia (Italy). Bollettino della Società Paleontologica Italiana, 23: 161-204.

Raevskaya, E. \& Golubkova, E. 2006. Biostratigraphical implication of Middle-Upper Cambrian acritarchs from Severnaya Zemlya (high Arctic of Russia). Review of Palaeobotany and Palynology, 139: 53-69.

Raevskaya, E.G. \& Servais, T. 2009. Ninadiacrodium: A new Late Cambrian acritarch genus and index fossil. Palynology, 33, 219-239.

Rasul, S.M. 1974. The Lower Palaeozoic acritarchs Priscogalea and Cymatiogalea. Palaeontology, 17: 41-63.

Rasul, S.M. 1976. New species of the genus Vulcanisphaera (Acritarcha) from the Tremadocian of England. Micropaleontology, 22: 479-484.

Rasul, S.M. 1979. Acritarch zonation of the Tremadoc Series of the Shineton Shales, Shropshire, England. Palynology, 3: 53-72.

Rauscher, R. 1973. Recherches micropaléontologiques et stratigraphiques dans l'Ordovicien et le Silurien en France. Études des acritarches, des chitinozoaires et des spores. Sciences Géologiques, Université Louis Pasteur de Strasbourg, Institut de Géologie, Mémoire, 38: 1-224.

Ribbert, K.-H., Servais, T. \& Vanguestaine, M. 2001. 4.28 Stavelot-VennAntiklinale (28). In: Stratigraphie von Deutschland II, Teil III. Courier Forschungsinstitut Senckenberg, 235: 68-89.

Ribecai, C. \& Vanguestaine, M. 1993. Latest Middle-Late Cambrian acritarchs from Belgium and northern France. Special Papers in Palaeontology, 48: 45-55.

Ribecai, C., Bagnoli, G., Mazzarini, F. \& Musumeci, G. 2005. Paleontological evidence for Late Cambrian in the Arburese area, SW Sardinia. Carnets de Géologie-Mémoire 2005/02, Abstract 8: 45-50.

Rubenstein, C.V., Mángano, M.G. \& Buatois, L.A. 2003. Late Cambrian acritarchs from the Santa Rosita Formation: implications for the Cambrian-Ordovician boundary in the Eastern Cordillera of northwest Argentina. Revista Brasileira de Paleontologia, 6: 43-48.

Rushton, A.W.A., Owen, A.W., Owens, R.M. \& Prigmore, J.K. 1999. British Cambrian to Ordovician Stratigraphy. Geological Conservation Review Series, 18. Joint Nature Conservation Committee, Peterborough, England, $x x i+435 p p$.
Servais, T. \& Eiserhardt, K.H. 1995. A discussion and proposals concerning the Lower Paleozoic 'galeate' acritarch plexus. Palynology, 19: 191-210.

Servais, T., Vecoli, M., Jun Li, Molyneux, S.G., Raevskaya, E.G. \& Rubinstein, C.V. 2007. The acritarch genus Veryhachium Deunff 1954: taxonomic evaluation and first appearance. Palynology, 31: 191-203.

Siveter, D.J., Williams, M. \& Waloszek, D. 2001. A phosphatocopid crustacean with appendages from the Lower Cambrian. Science, 293: 479-481.

Slavíková, K. 1968. New finds of acritarchs in the Middle Cambrian of the Barrandian (Czechoslovakia). Věstnik Ūstředního ústavu geologického, 43: 199-205.

Stricanne, L. \& Servais, T. 2002. A statistical approach to classification of the Cambro-Ordovician galeate acritarch plexus. Review of Palaeobotany and Palynology, 118: 239-259.

Stubblefield, C.J. 1930. A new Upper Cambrian Section in South Shropshire. Summary of Progress of the Geological Survey of Great Britain, for 1929, part 2: 54-62.

Szczepanik, Z. 1997. Preliminary results of thermal alteration investigations of the Cambrian acritarchs in the Holy Cross Mts. Geological Quarterly, 41: 257-264.

Szczepanik, Z. 2001. Acritarchs from Cambrian deposits of the southern part of the Lysogóry unit in the Holy Cross Mountains, Poland. Geological Quarterly, 45: 117-130.

Tawadros, E., Rasul, S.M. \& Elzaroug, R. 2001. Petrography and palynology of quartzites in the Sirte Basin, central Libya. Journal of African Earth Sciences, 32: 373-390.

Taylor, K. \& Rushton, A.W.A. 1972. The pre-Westphalian geology of the Warwickshire Coalfield, with a description of three boreholes in the Merevale area. Bulletin of the Geological Survey of Great Britain, 35: 1-152 [dated 1971].

Timofeev, B.V. 1958. Über das Alter sächsischer Grauwacken. Mikropaläophytologische Untersuchungen von Proben aus der Weesensteiner und Lausitzer Grauwacke. Geologie, 7: 826-845.

Timofeev, B.V. 1959. Drevneishaya flora Pribaltiki i ee stratigraficheskoe znachenie. Vsesoyuznyi Neftyanoi Nauchno-Issledovatelskii Geologorazvedochnyi Institut, Leningrad (VNIGRI), Trudy, 129: 11-136.

Tongiorgi, M. \& Ribecai, C. 1990. Late Cambrian and Tremadocian phytoplankton (acritarchs) communities from Öland (Sweden). Bollettino della Società Paleontologica Italiana, 29: 77-88.

Turner, R.E. 1984. Acritarchs from the type area of the Ordovician Caradoc Series, Shropshire, England. Palaeontographica Abteilung B, 190: 87-157.

Umnova, N.I. \& Vanderflit, E.K. 1971. Acritarch assemblages from Cambrian and Lower Ordovician sediments of the west and northwest Russian Platform. In: Palynological Research in Byelorussia and other regions of the USSR. Science and Engineering, Minsk: 45-73 [in Russian].

Vanguestaine, M. 1973. New acritarchs from the Upper Cambrian of Belgium. In: Microfossils of the oldest deposits, Proceedings of the Third International Palynological Conference, Novosibirsk, 1971. Akademiya Nauk SSSR, Siberskoe Otdelenie, Institut Geologii I Geofizikii, Izdatelstvo 'Nauka', Moskva: 28-30.

Vanguestaine, M. 1974. Espèces zonales d'acritarches du CambroTrémadocien de Belgique et de l'Ardenne française. [Zone species of acritarchs from the Cambro-Tremadocian of Belgium and the French Ardenne.] Review of Palaeobotany and Palynology, 18: 63-82.

Vanguestaine, M. 1978. Critères palynostratigraphiques conduisant à la reconnaissance d'un pli couché Revinien dans le Sondage de GrandHalleux. Annales de la Société Géologique de Belgique, 100: 249-276.

Vanguestaine, M. 1986. Progrès récents de la stratigraphie par Acritarches du Cambro-Ordovicien d'Ardenne, d'Irlande, d'Angleterre, du Pays de Galles et de Terre-Neuve orientale. [Advances in Cambro-Ordovician stratigraphy using Acritarchs in Ardennes, Ireland, England, Wales and eastern Newfoundland.] Annales de la Société géologique du Nord, 55: $65-76$. 
Vanguestaine, M. 2002. The Late Cambrian acritarch Cristallinium randomense: morphology, taxonomy and stratigraphical extension. Review of Palaeobotany and Palynology, 118: 269-285.

Vanguestaine, M. \& Brück, P.M. 2008. A Middle and Late Cambrian age for the Booley Bay Formation, County Wexford, Ireland: New acritarch data and its implications. Revue de Micropaléontologie, 51: 67-95.

Vanguestaine, M. \& Van Looy, J. 1983. Acritarches du Cambrien Moyen de la vallée de Tacheddirt (Haut-Atlas, Maroc) dans le cadre d'une nouvelle zonation du Cambrien. Annales de la Société Géologique de Belgique, 106: 69-85.

Vavrdová, M. 1966. Palaeozoic microplankton from central Bohemia. Casopis pro Mineralogii a Geologii, 11: 409-414.

Vavrdová, M. 1976. Excystment mechanism of Early Paleozoic acritarchs [Mechanismus excystace u rane paleozoickych akritarch.] Casopis pro Mineralogii a Geologii, 21: 55-64.

Vecoli, M. 1996. Stratigraphic significance of acritarchs in CambroOrdovician boundary strata, Hassi-Rmel area, Algerian Sahara. Bollettino della Società Paleontologica Italiana, 35: 3-58.

Vecoli, M. 1999. Cambro-Ordovician palynostratigraphy (acritarchs and prasinophytes) of the Hassi-R'Mel area and northern Rhadames Basin, North Africa. Palaeontographia Italica, 86: 1-112.

Volkova, N.A. 1990. Middle and Upper Cambrian acritarchs in the EastEuropean Platform. Academy of Sciences of the USSR, Transactions, 454: 116pp. [in Russian].

Volkova, N.A. \& Golub, I.N. 1985. Novye akritarkhi verkhnego kembriya Leningradskoy oblasti (Ladozhskaya svita) [New Upper Cambrian acritarchs from the Leningrad Oblast (Ladoga Formation).] Paleontologicheskii Zhurnal, 19: 90-98.

Volkova, N.A. \& Kir'yanov, V.V. 1995. Regional Middle-Upper Cambrian stratigraphic scheme of the East European Platform. Stratigraphy and Geological Correlation, 3: 66-74.
Wahlenberg, G. 1821. Petrificata telluris Svecana examinata. Nova Acta Regiae Societatis Scientiarum Upsaliensis, 8: 1-116, 293-297.

Welsch, M. 1986. Die Acritarchen der höheren Digermul-Gruppe, Mittelkambrium bis Tremadoc, Ost-Finnmark, Nord-Norwegen. [The acritarchs of the Upper Digermul Group, Middle Cambrian to Tremadoc, eastern Finnmark, northern Norway.]. Palaeontographica Abteilung B, 201: 1-109.

Westergård, A.H. 1922. Sveriges Olenidskiffer. Sveriges Geologiska Undersökning, Avhandlingar och uppsatser, Ser. Ca, 18, 205pp.

Westergård, A.H. 1944. Borrningar genom Skånes alunskiffer 1941-42. Sveriges Geologiska Undersökning, C, 459: 1-45.

Wood, G.D. \& Stephenson, J.T. 1989. Cambrian palynomorphs from the warm-water provincial realm, Bonneterre and Davis Formations of Missouri and Arkansas (Reelfoot Rift area): biostratigraphy, paleoecology and thermal maturity. In: Gregg, J.M., Palmer, J.R. \& Kurtz, V.E. (Eds), Field Guide to the Upper Cambrian of Southeastern Missouri: Stratigraphy, Sedimentology and Economic Geology, Department of Geology and Geophysics, University of Missouri (Rolla), Geological Society of America Field Trip (Annual Meeting): 84-102.

Yin, Lei-ming. 1986. Acritarchs. In Chen, Jun-Yuan (Ed.), Aspects of Cambrian-Ordovician boundary in Dayangcha, China. China Prospect Publishing House, Beijing, 314-373.

Young, T., Martin, F., Dean, W.T. \& Rushton, A.W.A. 1994. Cambrian stratigraphy of St Tudwal's Peninsula, Gwynedd, northwest Wales. Geological Magazine, 131: 335-360.

Young, T.P., Gibbons, W. \& McCarroll, D. 2002. Geology of the country around Pwllheli. Memoir for 1:50,000 Geological Sheet 134 (England and Wales). British Geological Survey, 145pp.

Żylińska, A., Szczepanik, Z. \& Salwa, S. 2006. Cambrian of the Holy Cross Mountains, Poland; biostratigraphy of the Wiśniówka Hill succession. Acta Geologica Polonica, 56: 443-461. 